\title{
COMPULSORY POOLING UNDER THE OIL AND GAS CONSERVATION ACT OF ALBERTA
}

\author{
NIGEL BANKES
}

This article provides a comprehensive analysis of compulsory pooling orders issued by the Energy and Utilities Board and its predecessors under the Alberta Oil and Gas Conservation Act The author describes the history and purpose of compulsory pooling provisions, outlines the statutony framework, and analyzes the procedures, jurisdiction and powers of the EUB. The article then describes the salient features of compulsory pooling orders, focusing on contentious issues such as cost equalization, and looks at the effects of such orders. The author argues that EUB decisions are largely consistent, although occasionally provide inadequate reasons. The author submits that the Lieutenant Governor in Council should no longer be involved in EUB pooling orders, rather, the best protection for the industry is to require the EUB to provide clear written decisions which are consistent with its own precedents and subject to judicial review or appeal. Finally, the author points out that in some situations compulsory pooling orders may be more generous to working interest owners than voluntary pooling agreements.
Le présent article fournit une analyse poussée des ordonnances de mise en commun obligatoire émanant du l'Alberta Energy and Utilities Board et de ces prédécesseurs aux termes de l'Alberta Oil and Gas Conservation Act. L'auteur décrit l'histoire et le but des dispositions à cet égard, le cadre prévu par la loi, et il analyse les procédures, la compétence et les pouvoirs du EUB. L'article dégage ensuite les points saillants des ordonnances, met l'accent sur des questions contentieuses telles que l'égalisation des coûts, et en examine les conséquences. Selon l'auteur, les décisions du EUB sont en grande partie cohérentes, quoiqu'elles invoquent parfois des raisons inadéquates. $L$ 'auteur estime que le lieutenant gouverneur en conseil ne devrait plus participer aux ordonnances de mise en commun du EUB et que, pour sa protection, l'industrie doit exiger que le EUB fournisse des décisions écrites claires, conformes à ses propres précédents et susceptibles de recours en révision ou d'appel. L'auteur souligne enfin que dans certains cas, les ordonnances de mise en commun obligatoire avantagent peut-être plus les détenteurs d'un intérêt économique direct que ne le font les accords de mise en commun volontaire.

\section{TABLE OF CONTENTS}

I. INTRODUCTION . . . . . . . . . . . . . . . 947

II. HISTORY OF AND RATIONALE FOR THE COMPULSORY POOLING PROVISIONS OF THE OGCA ........... 949

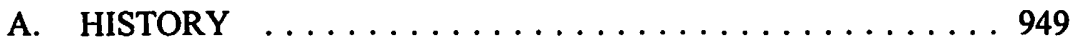

B. RATIONALE ..................... 950

III. AN OVERVIEW OF PART XII AND BOARD

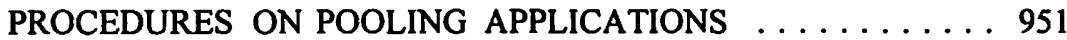

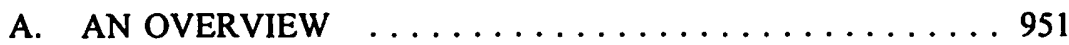

B. BOARD PROCEDURE FOR DEALING

WITH APPLICATIONS $\ldots \ldots \ldots \ldots \ldots \ldots \ldots \ldots 2$

Professor, Faculty of Law, University of Calgary. I would like to thank the staff of the library of the Energy and Utilities Board in Calgary, especially Angela Jones, for their assistance. I would also like to thank the following individuals for their comments on an earlier draft of the article: Steven Kennett, Alan Hunter, Jim Eamon and Tania Donnelly. The present article is a considerably expanded and more thoroughly researched version of my portion of a jointly authored conference paper: N. Bankes and E.M. Shier, "Pooling Agreements and Pooling Orders" (Paper presented to the Insight Conference on Oil and Gas Exploration Agreements, Calgary, 5 November 1996) [unpublished]. 
C. A SUMMARY OF BOARD POOLING ORDERS . . . . . 953

IV. WHEN CAN THE BOARD GRANT AN ORDER? . . . . . . 955

A. APPLICATION FROM THE OWNER OF A TRACT . . . 955

B. MULTIPLE TRACTS WITHIN THE DSU ..........956

C. EVIDENCE THAT AN AGREEMENT TO OPERATE THE TRACTS AS A UNIT CANNOT BE MADE ON REASONABLE TERMS . . . . . . . . . . . . . . 957

D. OTHER REASONS FOR DENYING AN APPLICATION .. 959

V. SPECIAL CASES: CONCURRENT PRODUCTION

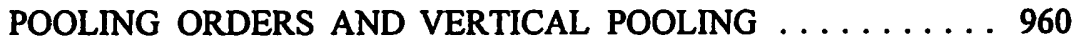

A. CONCURRENT PRODUCTION $\ldots \ldots \ldots \ldots \ldots \ldots \ldots 96$

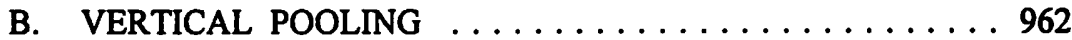

VI. THE ELEMENTS OF THE ORDER:

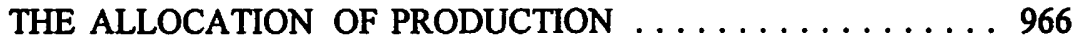

A. PRESUMPTION IN FAVOUR OF

ACREAGE ALLOCATION ............... 966

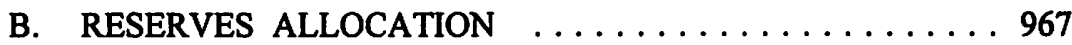

VII. ELEMENTS OF THE ORDER: SUBSTANCES AND ZONES . . . 969

A. ALL ZONES DOWN TO THE BASE OF A

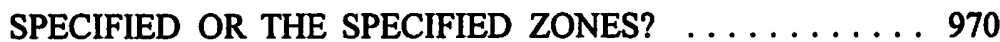

B. THE POOLED SUBSTANCES $\ldots \ldots \ldots \ldots \ldots \ldots \ldots 970$

VIII. ELEMENTS OF THE ORDER:

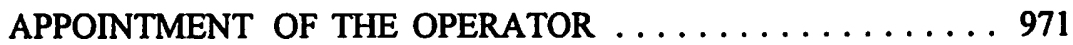

A. CONTENTIOUS CASES ................971

B. RIGHTS AND OBLIGATIONS OF AN

OPERATOR WITH RESPECT TO PRODUCTION ...... 974

IX. ELEMENTS OF THE ORDER: TIMING OF THE WELL . . . . . 976

$X$. ELEMENTS OF THE ORDER:

ALLOCATION OF COSTS OR EQUALIZATION ........ 976

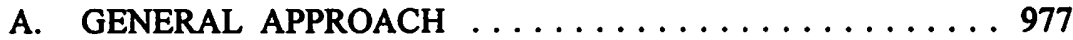

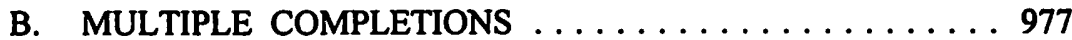

C. CONCURRENT PRODUCTION SCENARIOS ........981

D. COSTS NOT INCURRED BY THIS APPLICANT

OR BY PARTIES TO THE PRESENT APPLICATION . . . 982

E. TREATMENT OF DOWNSTREAM COSTS ......... 983

F. COSTS OF, AND RESPONSIBILITY

FOR, ABANDONMENT . . . . . . . . . . . . . 984

XI. ELEMENTS OF THE ORDER: THE PENALTY PROVISION . . 987

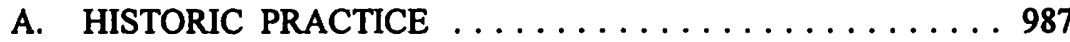

B. CURRENT PENALTY PRACTICE ............ 989

C. TREATMENT OF PRODUCTION

DURING THE PENALTY PERIOD . . . . . . . . . . . 993

XII. ELEMENTS OF THE ORDER:

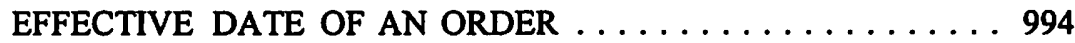

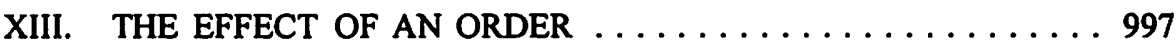

XIV. AMENDMENTS AND THE BOARD'S

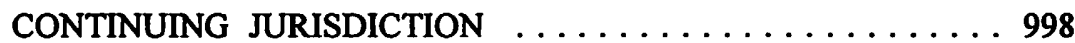




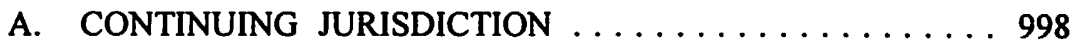

B. AMENDMENTS . . . . . . . . . . . . . . . . . 999

XV. POOLING ORDERS AND UNITIZATION $\ldots \ldots \ldots \ldots \ldots 1002$

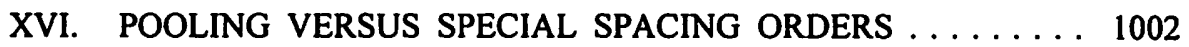

A. THE REGULATIONS $\ldots \ldots \ldots \ldots \ldots \ldots \ldots \ldots \ldots 1002$

XVII. CONCLUSIONS ..................... 1007

\section{INTRODUCTION}

A previous article on "Pooling Agreements in Canadian Oil and Gas Law"' dealt only peripherally with the subject of compulsory pooling orders. The present article analyzes the law and practice of compulsory pooling orders in Alberta.

The primary purpose of this article is to present a detailed analysis of the compulsory pooling provisions of the Alberta Oil and Gas Conservation Act (Part XII) ${ }^{2}$ along with an account of their interpretation by the Energy and Utilities Board. ${ }^{3}$ While there are several discussions of Board practice in relation to compulsory pooling orders, ${ }^{4}$ none purports to be exhaustive or comprehensive. These discussions give some account of Board decisions but pay less attention to the much larger number of examiners' reports and even less (if any) attention to the form of the pooling order. This article provides a systematic account of those decisions, and the form of the order.

A secondary objective of the article is to provide some commentary on the role of precedent within an administrative tribunal like the EUB. Since 1958, the Board (or its predecessors) has recommended approval of some 150 compulsory pooling orders. Many of these orders were preceded by a report from the Board itself, or a panel of examiners appointed by the Board. ${ }^{5}$ With a few notable exceptions, these decisions do not refer to earlier decisions of the Board or the reports of its examiners. Neither do they justify why they are departing from an established practice, or indeed following a body of precedent where one can be established. In order to illustrate this point at the outset, here is an example from the body of decisions dealing with "cost equalization." "Cost equalization" is often an integral and contentious aspect of a compulsory pooling order. Shorn of unnecessary jargon, "equalization" is the process of determining which of the costs incurred by the applicant should be subject to sharing under the terms of

' N. Bankes, "Pooling Agreements in Canadian Oil and Gas Law" (1995) 33 Alta. L. Rev. 493.

2 R.S.A. 1980, c. O-5 [hereinafter OGCA or the $A c t$ ]; the EUB was established by the Energy and Utilities Board Act, S.A. 1994, c. A-19.5.

3 Hereinafter the EUB or the Board. The term "Board" is also used to refer to whichever board happened to be the regulator at the time (i.e. the Oil and Gas Conservation Board (1957-1971) or the Energy Resources Conservation Board (1971-1994)).

$4 \quad$ See authorities cited in Bankes, supra note 1 at note 3; and see also M.J. Sychuk, "Conservation: Is it Justified in the Public Interest?" (1969) 7 Alta. L. Rev. 355.

5 The authority to refer a matter to a panel of examiners is found in the Energy Resources Conservation Act, R.S.A. 1980, c. E-11, ss. 16(d), 17 and 36 [hereinafter ERCA]. The Board rejected an objection to a panel of examiners in: Application by Ashlu Exploration Ltd., Compulsory Pooling, Elnora Field, Examiners' Report E 82-2 at I [hereinafter Ashlu]. The Board subsequently confirmed the resulting report in Decision D 82-10. See also Caribe Holdings Ltd. v. The Alberta Energy Resources Conservation Board (1978), 13 A.R. 132 (C.A.). 
a compulsory pooling order with another tract owner in a spacing unit. A concrete set of facts will help illustrate the point. Suppose that $B$ drills a well to zone $Z$ to explore for oil. B is unsuccessful but discovers gas in the shallower Y zone. Later, B decides to complete the well in the $\mathrm{Y}$ zone for the purposes of producing gas. $\mathrm{C}$ owns the balance of the drilling spacing unit for gas and $B$ and $C$ are unable to reach agreement on the sharing of the drilling costs. In order to resolve the dispute and commence production, B applies to the Board for a compulsory pooling order.

This is a typical example of the type of dispute that has been coming before the Board with increasing frequency in the last few years. The Board provided guidance on the relevant principles in a well reasoned decision in Gulf's Fenn-Big Valley application in $1990 .^{6}$ Yet, since then, subsequent decisions of the examiners reflect a lack of consistency at the level of principle. This is disturbing for a number of reasons. First, if the decisions of examiners become less predictable, parties will be less likely to settle their disputes by agreement than if it were possible to predict with some confidence the principles to be applied if the dispute were referred to the Board. Second, even if an administrative tribunal is not bound by formal rules of precedent, it is an important principle of justice that like cases be treated alike. It is unfair if panels of examiners apply different principles to essentially the same fact patterns. Third, and related to the last point; inconsistent decision-making may have an impact on the degree of deference owed to the tribunal by the courts. ${ }^{7}$

In light of this subsidiary theme, this article shall identify situations in which the Board's treatment of similar fact problems seems to be inconsistent. In the conclusion, it will return to consider the legal implications of inconsistent decision-making and make some additional comments on the quality of the reasons offered by the Board and its examiners for their decisions.

In this article, the term compulsory pooling order is used to refer to an order of a conservation board that combines all the tracts within a Drilling Spacing Unit (DSU), so as to permit the licensing and production of a well in accordance with the terms of the $O G C A^{8}$ and regulations. ${ }^{9} \mathrm{~A}$ "tract" is simply an area of the spacing unit for which the working interest ownership differs from other portions of the DSU. ${ }^{10}$

6

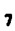

7

Gulf Canada Resources Ltd., Compulsory Pooling, Fenn-Big Valley Field, Decision D 90-9 [hereinafter Gulf Fenn-Big Valley].

Domtar Inc. v. Quebec (Commission d'appel en matière de lésions profesionnelles) (1993), 105 D.L.R. (4th) 385 (S.C.C.) provides a recent and nuanced review of the authorities (discussed below: see text accompanying notes $295 \mathrm{ff}$ ).

Supra note 2; s. 11 states that no person shall drill or produce without a licence; s. 13 provides that no person shall apply for a licence unless entitled, or is the authorized representative of the person entitled, to the right to produce the oil, gas, or crude bitumen for the recovery or evaluation of which the well is to be drilled, and s. 12 provides that no person shall apply for a licence for a well for obtaining production from the same pool, in the same DSU, without the approval of the Board. Collectively, these sections establish the rule that there shall (ordinarily) be only one well per pool per DSU. 


\section{HISTORY OF AND RATIONALE FOR THE COMPULSORY POOLING PROVISIONS OF THE OGCA}

\section{A. HISTORY}

The current compulsory provisions of the Act have scarcely been amended since they were first introduced in a comprehensive amendment to the $O G C A$ in 1957." Prior to that amendment, the Act was silent on compulsory pooling, although it did contain provisions (on which the current s. 71 of the Act is modelled) according the Board a responsibility to encourage pooling. ${ }^{12}$ Also introduced in 1957 were the compulsory unitization provisions of the Act. These provisions, although still on the statute book, have never been proclaimed. ${ }^{13}$ They were removed from the sequential numbering of the $O G C A$ in 1980 as part of the preparation of the 1980 Revised Statutes; they are now found in a supplement to the Revised Statutes. ${ }^{14}$

This last point is mentioned here because it helps explain the sub-headings that are used in what is now Part XII of the Act. When originally introduced, the structure of this part of the Act was as follows. The two "originating sections" for a compulsory pooling application (now ss. 72 and 73) dealing, respectively, with the case of the well already drilled and the well to be drilled (both under the heading "pooling") were followed immediately by the compulsory unitization provisions headed "unit operation in a field or pool." These provisions were then followed by a heading marked "General."

The historical structure seems to make it clear that the so-called "general provisions" were grouped together largely because they were intended to deal with situations that were common to forced unitization and pooling. With the failure to proclaim the compulsory unitization provisions of the statute, the word "general" is now an awkward term for some of the provisions.

As originally drafted in 1957, the Act was silent on a number of matters that are now addressed in some detail. For example, in 1959, the Act was amended to add provisions dealing with amendment or termination of an order as well as to define the term "the

OGCA, S.A. 1957, c. 63, Part VIII, ss. 71 to 89. R. Harrison, "Regulation of Well Spacing In Oil and Gas Production" (1970) 8 Alta. L. Rev. 357 provides an account of the history of spacing in Alberta at 368-72. He does not discuss the history of the compulsory pooling provisions but does present an analysis of the then current (1970) provisions at 373-74. D. Breen, Alberta's Petroleum Industry and the Conservation Board (Edmonton: University of Alberta Press, 1993) at 501-502 provides a very short account of the 1957 revisions noting that "the most important amendments from the Board's perspective were the new section on pooling and the greatly expanded section on unitization."

S.A. 1950 , c. 46 , s. 95 .

13 On the continuing significance of these provisions and the consequential limits on the Board's capacity to impose conservation schemes, see Cabre Exploration Ltd., Gas Injection/Rateable Take/ Common Carrier/Common Processor, Kakwa A, Cardium A Pool, Examiners' Report E 96-3 and the related Decision D 96-6. 
actual cost of drilling a well"; 15 in 1962 the Act was amended to deal with the specific problem of including a pooled unit within a unitization agreement and to expand and further clarify the powers of the Board to deal with an amendment to a pooling order. $^{16}$

Since 1980, there have been two significant changes to this Part of the Act. First, as part of a set of procedural revisions in 1988, the Act was amended to relieve the Board from the responsibility of "hearing" all applications for a pooling order or an amendment thereof. ${ }^{17}$ Second, the penalty section of the Act was amended in 1990 to provide that the Board could raise the penalty from 50 percent of the drilling costs to 200 percent of the drilling costs where a tract owner declines to contribute to the cost of drilling and completing the well within the time prescribed by the Board. ${ }^{18}$

In sum, although there have been a number of changes, the overall structure of the Part has remained essentially the same since first introduced in 1957. Certainly none of these changes has effected fundamental reform to a statutory scheme that seems to have worked relatively well for forty years.

\section{B. RATIONALE}

The compulsory pooling order is one regulatory response to the introduction of spacing requirements for wells. The American experience, especially that of Texas, suggests that it is not a necessary corollary of spacing requirements, ${ }^{19}$ but it is by far the most effective method of dealing with the problems occasioned by spacing requirements. It also meets one of the main objectives of oil and gas conservation legislation, namely, to accord each owner the opportunity to obtain the owner's share of the oil and gas from the pool. ${ }^{20}$ Where there are multiple tract owners within a spacing unit, no party may drill a well in the absence of an agreement between all tract owners. ${ }^{21}$ If the parties are unable to reach agreement, for whatever reason, tract owners will be denied their opportunity to recover their share of reserves. Hence, the need for a mechanism for imposing an arrangement under which all tract owners within the DSU

S.A. 1959 , c. 59 , s. 13.

S.A. 1962 , c. 59 , s. 20 .

S.A. 1988 , c. 37 , ss. $9-11$.

S.A. 1990 , c. 30 , s. 3.

Texas did not have a compulsory pooling statute until 1964. See E.E. Smith, "The Texas Compulsory Pooling Acts" (1965) 43 Tex. L. Rev. 1003 (Part 1) and (1966) 44 Tex. L. Rev. 387 (Part 2); and B. Kramer \& P. Martin, The Law of Pooling and Unitization, 3d ed. (New York: Matthew Bender, 1989) at para. 10.01. For many years in Texas, the owner of a small tract was entitled to drill a well as of right and to obtain a "living allowable" sufficient to allow the well to recover the cost of drilling and operating. To deny a tract owner the right to drill such a well would constitute an unlawful taking, but on the other hand, fixing a living allowable was in effect an unlawful taking from larger tract owners. It was on this last basis that the living allowable system was eventually struck down by the Texas Supreme Court, which action led directly to a forced pooling statute (see ibid.).

$O G C A$, supra note 2 , s. 4.

See the references and discussion in supra note 8. 
will pool their tracts for the purposes of forming a unit to permit exploration for, and production of, the pooled substances. ${ }^{22}$

\section{AN OVERVIEW OF PART XII AND BOARD PROCEDURES ON POOLING APPLICATIONS}

\section{A. AN OVERVIEW}

Part XII of the Act is currently comprised of thirteen sections (ss. 70 to 82) with s. 70 serving as a definition section and s. 71 dealing with the Board's responsibility to encourage unitization operations. Of the balance of the provisions, ss. 72 and 73 form the heart of the pooling provisions. These are the only two sections that permit an original application as opposed to an application to amend an existing order.

Section 72 prescribes the contents of an application as well as the minimum content of a Board order. The Board can only make an order with the approval of the Lieutenant Governor in Council. While s. 72 deals with the situation where the applicant has yet to drill a well, s. 73 deals with the case where a well has already been drilled. Section 73 incorporates by reference all the relevant procedural and substantive provisions of $\mathrm{s}$. 72. Section 75 , which defines the term "actual drilling costs" for the purposes of equalization and penalty, serves as an additional definitional section for these two sections.

The circumstances under which the Board can amend an order are detailed in s. 74, while s. 76 deals with the problem of pooling orders where part of the DSU, already included within a pooling order, is brought within the scope of a unitization agreement. Finally, the general provisions which close out this Part of the Act deal with the situation of a missing or an untraceable tract owner (s. 77); and arrangements to be made in the event of a dispute as to which party is entitled to receive production under a Board order (s. 78); the effect of an order (ss. 79 and 82); several liability for operating expenses; and a provision (s. 81) which makes it clear that no order can be amended or terminated except in accordance with this Part.

The Act still specifies that no order of the Board may be issued without the approval of the Lieutenant Governor in Council. This requirement applies to the issuance of an order (s. 72(3)) and the termination or variation of an order (s. 74(3)). As a matter of practice, Board recommendations are routinely accepted. ${ }^{23}$ There is one exception to the requirement of Lieutenant Governor in Council approval. Where the Board order specifies that a well is to be drilled within a specific time and the well is not drilled within that time, the Board may terminate the order without a hearing, notice or the approval of the Lieutenant Governor in Council. ${ }^{24}$ 
There is a suggestion in some decisions of the Board and its Examiners that there are multiple forms of applications under Part XII of the Act. Thus, some decisions refer to a s. 77 application (missing or untraceable tract owner) ${ }^{25}$ or a s. 78 application (a dispute regarding production ${ }^{26}$ ). This is a mischaracterization of the scheme of this part of the Act. It is submitted here that the Act only permits three types of pooling applications: (1) an application under s. 72 where a well has already been drilled; (2) an application under s. 73 where a well has yet to be drilled; and (3) an application under s. 74 or 76 to amend a s. 72 or s. 73 order. Each of these applications must meet the criteria established by s. 72 . Sections 77 and 78 perform an ancillary role and do not provide an independent jurisdiction for the Board. Thus, s. 77 provides that "an order under this Part" (i.e. pursuant to ss. 72 or 73) may include provisions for the sale of production where a tract owner is missing or untraceable.

This distinction may seem a fine one but its importance is this. If there were such a thing as a s. 77 order, it would appear that an order could be made without first having satisfied the requirements of ss. 72 or 73 . That would be wrong. Section 77 provides no independent source of jurisdiction for making an order, it merely permits additional terms to be added if there is already a basis for making an order under s. 72 or s. 73. The point may be more important for $\mathbf{s .} 78$ (dealing with disputes as to title to production), for, despite Board decisions to the contrary, ${ }^{27}$ this section does not provide any jurisdiction to the Board. It does not provide an additional ground upon which a party may make an application to the Board, and neither does it authorize the inclusion of additional terms in a pooling order.

\section{B. BOARD PROCEDURE FOR DEALING WITH APPLICATIONS}

The Board has not prescribed a standard form for a compulsory pooling order application. ${ }^{28}$ However, the Act itself does prescribe the minimum content of an application. Thus s. 72(2) specifies that an applicant shall state in its application:

(a) the legal description of each tract within the drilling spacing unit and the ownership of that tract,

(b) the formation to which he proposes to drill, or from which he proposes to produce,

(c) that an agreement to operate the tracts as a unit cannot be made on reasonable terms, 
(d) particulars of efforts made by him to obtain agreement to the operation as a unit of all tracts within the drilling spacing unit,

(e) if there is a well on the drilling spacing unit, the name of the well and its producing formation or formations,

(f) if there is not a well on the drilling spacing unit to the formation referred to in clause (b), that if an order is made by the Board he is prepared to drill a well to a specified depth of that formation and, in the event that no production of oil or gas is obtained, he will pay all costs incurred in the drilling and abandonment of the well.

Upon receipt of an application, Board staff will check the contents to see that the application is complete. Staff will then make an attempt to get the parties to settle their dispute without the need for formal consideration by the Board by calling the principal parties to attempt to determine key areas of difficulty. Occasionally, parties will advise staff that they have little objection to a pooling order but are not prepared to devote the time and resources to negotiating a pooling agreement, perhaps because they place little value on the property. In such a case, the Board will process the application administratively and will not call an examiners' hearing. The Board will advertise and provide notice of the application to tract owners along with the proposed terms of the order. Where parties object, the Board will schedule an examiners' hearing. In some cases, parties will ask for the application to be put on hold pending further attempts at settlement. Board staff estimates that about one third of all applications are withdrawn without the need for a Board order. It is rare for a pooling application to be referred for a hearing by the Board rather than by the examiners. ${ }^{29}$

\section{A SUMMARY OF BOARD POOLING ORDERS}

During the preparation of this article all the 150 or so pooling orders that have been issued by the Board between 1957 and December 1996, as well as most of the decisions of the Board and its examiners, were reviewed. Some of the data is presented in Table 1 and several observations are in order.

This paragraph is based on information obtained from Fisher, ibid. Ms. Fisher noted that of the thirty-two applications received by the Board in 1996, seven had been withdrawn by year-end and she expected a further two or three to be withdrawn. She reported that a one-third withdrawal rate was typical. Although decisions of examiners are typically confirmed by the Board without attracting further opposition, in the case of Imperial Oil's Willesden Green application (see infra note 154), the intervenor objected to the recommendations of the examiners. The Board considered the objection and confirmed the examiners' report. 
Table 1

POOLING ORDERS ISSUED BY THE BOARD, 1957-1996

\begin{tabular}{|c|c|c|c|c|c|}
\hline $\begin{array}{c}5 \text { year } \\
\text { periods Jan- } \\
\text { Dec }\end{array}$ & $\begin{array}{c}\text { Acreage- } \\
\text { based orders }\end{array}$ & $\begin{array}{c}\text { Reserves- } \\
\text { based orders }\end{array}$ & $\begin{array}{c}\text { Missing tract } \\
\text { owners }\end{array}$ & $\begin{array}{c}\text { Total orders } \\
\text { minus } \\
\text { missing tract }\end{array}$ & $\begin{array}{c}\text { Total number } \\
\text { of orders }\end{array}$ \\
\hline \hline $1957-1961$ & 17 & 2 & 2 & 17 & 19 \\
\hline $1962-1966$ & 9 & 5 & 1 & 13 & 14 \\
\hline $1967-1971$ & 2 & 1 & 0 & 3 & 3 \\
\hline $1972-1976$ & 3 & 1 & 1 & 3 & 4 \\
\hline $1977-1981$ & 8 & 3 & 2 & 9 & 11 \\
\hline $1982-1986$ & 32 & 4 & 22 & 13 & 35 \\
\hline $1987-1991$ & 22 & 0 & 6 & 16 & 22 \\
\hline $1992-1996$ & 38 & 4 & 10 & 32 & 42 \\
\hline \hline TOTAL & 131 & 20 & 44 & 106 & 150 \\
\hline
\end{tabular}

Notes:

1. The table covers Pooling Orders No. 1-153, inclusive.

2. Pooling Order No. 149 was not issued during 1996. Order No. P 70 simply recinds No. P 69; Order No. P 121 does not appear to have been issued. Order No. P 85 (1986), which provides for acreage-based pooling in the Viking and reserves-based pooling in the Leduc, is double-listed for the 1982-1986 period.

First, my hypothesis, prior to examining the orders, was that the most common reason (apart from the situation of missing tract owners) for parties to seek a compulsory pooling order would be because they could not agree on the allocation of reserves. It therefore is surprising how few reserves-based pooling orders the Board has actually issued (twenty). Although it is undoubtedly the case that in some other decisions the applicants had sought, but were denied, reserves-based pooling, in many other cases it is clear that other factors led an owner to apply for a compulsory pooling order. These factors, in addition to the situation of the missing tract owner, include: inability to agree on equalization costs, difference in opinion as to whether the reserves discovered are commercial, refusal of oil well owners to share gas cap production with other tract owners within the gas DSU, and perhaps an unwillingness to contribute to the capital costs of tie-in facilities, or an inability to market production and yet an unwillingness to pay marketing fees.

Second, the number of applications involving missing tract owners varies markedly. A review of Board decisions on this point indicates that demand for pooling orders for this reason is likely occasioned by exploration occurring in an area that was previously subdivided but which is no longer occupied (e.g. an abandoned town or a townsite laid out in advance of railway construction but never developed as a result of route changes). Consequently, in determining whether parties are making more or less use of the Board's compulsory pooling jurisdiction it is most useful to consider the total number of orders minus the number of missing tract owner orders. 
These figures show that the number of completed orders has been growing steadily over the last fifteen years. The reasons for this are not entirely clear. Relevant factors no doubt include variations in the numbers of wells drilled in the province, increasing frequency of multiple zone completions, and the use of pooling orders in the gas cap production scenario. It is also worth posing one additional research question at this stage. To the extent that the terms of the Board's standard pooling order may be more favourable than those that a tract owner would ordinarily be able to negotiate in the industry, is there an incentive for some parties to use the compulsory pooling order? This question will be returned to in the conclusion, but in the course of the article it will be noted where the form of the Board order seems to depart from standard practice in industry pooling and operating agreements. These differences include: a penalty that is lower than normal for non-participants; no opportunity for the operator to charge marketing fees for marketing a tract owner's share of production; and a tract owner's liability for abandonment is first and foremost a liability of the operator in that the operator can only recover from other tract owners out of actual production.

\section{WHEN CAN THE BOARD GRANT AN ORDER?}

Before the Board can grant an order there must be: (1) an application from the owner of a tract, (2) multiple tracts within the DSU, and (3) evidence that an agreement to operate the tracts as a unit cannot be made on reasonable terms.

\section{A. APPLICATION FROM THE OWNER OF A TRACT}

Section 72(1) of the $O G C A$ states that "The owner of a tract within a drilling spacing unit may apply to the Board for an order." The Board has no right to grant a pooling order of its own motion although it may vary an existing order of its own motion. ${ }^{30}$ The terms "owner" and "tract" are both defined terms for this Part of the Act. A "tract" is an area within a DSU within which an owner has the right or an interest in the right to drill for and produce oil or gas. Thus, tract is defined in terms of an area within which a person (the owner) has a working interest (the right to drill and produce), and not a passive interest like a royalty interest. ${ }^{31}$ The term "owner" when used in

Section 74(2) of the OGCA, supra note 2, provides that where the Board is of the opinion that pooling is not necessary to make up the DSU, or the well permitted by the order has not been drilled, or the well obtains production of a kind other than that contemplated, the Board may hold a hearing and consider in what manner the order should be varied, amended or terminated. See more detailed discussion below at Part XIV.

" Only a tenant in common, the holder of an undivided interest, has the right to go on to the lands and produce. Most royalty owners will not hold an undivided interest although some of the gross royalty trusts that have been created certainly go this far. See for example, the Security Trust form discussed in the GRTA Test Cases (1993), 8 Alta. L.R. (3d) 225, affd (1994), 23 Alta. L.R. (3d) 193 (C.A.) and reproduced at (1994), 138 A.R. 387. There is also authority for suggesting that the royalty reserved by a lessor may itself be a profit a prendre (see ibid. at paras. 31 and 111 , and also the decision of O'Leary J. in Scurry-Rainbow Oil Lid. v. Kasha (1996), 184 A.R. 177 (C.A.)). These cases are mistaken on this last point for at least two reasons: (1) a profit implies the right to go on to the land of another (i.e. the corporeal estate of another) and take and remove something of value; and (2) the typical lease grants the lessee the exclusive right (i.e. the exclusive profit) to take and remove, and the lessor will not ordinarily be a tenant in common of that 
connection with a tract as it indubitably is in $\mathbf{s .} 72$ of the Act, "includes the person who has the right or an interest in the right to drill for, produce and dispose of any oil or gas from the tract." This phrase must include the sole owner or tenant-in-common of a tract that has yet to be leased, as well as the holder of an undivided interest in a lease where one has been granted. Whether the term is limited to these persons is not entirely clear given the use of the word "includes" in the definition, but it is hard to bring a royalty holder within the scope of the persons entitled to make a s. 72 application (because a royalty owner does not, ordinarily, have the right to drill for, or to produce, oil or gas) or a lessor that has already accorded exclusive rights to a lessee. Such a person may be an owner in some general sense but they are not "the owner of a tract" for the purposes of this Part of the Act. ${ }^{32}$ Thus, while lessors and royalty owners would be entitled to intervene in a pooling application (and they occasionally have ${ }^{33}$ ) they probably do not have the authority to commence an application. ${ }^{34}$

\section{B. MULTIPLE TRACTS WITHIN THE DSU}

Several paragraphs within s. 72 make it clear that the existence of more than one tract is a condition precedent to the grant of a compulsory pooling order. ${ }^{35}$ Where the DSU is not divided into tracts, the Board established in its 1971 Spruce Oils ${ }^{36}$ decision that an owner will not be allowed to proceed with an application. Furthermore, such an application is not necessary because any owner (i.e. any tenant-in-common) within a single tract DSU may obtain a licence to drill a well. ${ }^{37}$

Where there are multiple tracts, the Board has the jurisdiction to grant an order even if one party holds an undivided interest within each tract of the DSU. ${ }^{38}$ The rationale

profillease.

Note that s. 74(1)(a) of the OGCA, supra note 2 (which is concerned with amendments), contemplates that an application for an amendment may be made by a working interest owner. It would be anomalous if a royalty holder had no right to commence an application for an amendment but did have the right to commence the original application. Note further that while paragraph (b) of s. 74(1) uses the term "any owner," in the context this must mean the owner of any working interest, however small. The term owner is used in several different places in the Act (e.g. s. 4) whereas in other places the $A c t$ adopts the more specific term "working interest participant" (s. 20.3 and s. 56.1).

See for example, Mission Resources Ltd., Compulsory Pooling, Riviere Area, Examiners' Report E 94-3 [hereinafter Mission Resources].

34 See also Bankes, supra note 1 at note 185.

35 For example, s. 72(1) speaks of an owner applying for an order that "all tracts" within the DSU be operated as a unit; s. 72(2)(d) speaks of details of efforts made to obtain agreement of "all tracts," and s. 72(4) speaks of an allocation of production "to each tract." Pooling, Leduc-Woodbend, Decision D 71-16.

Ibid.

Blue Range Resources Ltd., Application to Amend Well Licence No. 0124875, Sylvan Lake Field, Decision D 90-12, discussed in Bankes, supra note 1 at 503-506; PB Resources Inc., Application for Board Directed Transfers of Well Licences, Regranting of Pipeline and Compulsory Pooling, Examiners' Report E 95-13 [hereinafter PB Resources.] 
for this must be that in the absence of such an order or a pooling agreement, there would be no basis on which to allocate production within the DSU. ${ }^{39}$

\section{EVIDENCE THAT AN AGREEMENT TO OPERATE THE TRACTS AS A UNIT CANNOT BE MADE ON REASONABLE TERMS}

As recited above, s. 72(2) of the Act requires an applicant to state in its application that "an agreement to operate the tracts as a unit cannot be made on reasonable terms." The goal of this requirement is to encourage owners to resolve their differences without the intervention of the Board. But are good faith negotiations on the part of the applicant a condition precedent to jurisdiction? Or, are they simply a basis upon which the Board may exercise its discretion not to grant an order if unconvinced that negotiations have been pursued as far as they might? Both the Board's practice and the statutory text support the latter interpretation.

The requirement of negotiations is included in subsection (2) which reads more like a list of information that must be provided, rather than as a list of conditions precedent to jurisdiction. Board decisions typically proceed with a recitation of the period over which the parties engaged in negotiations and highlight the differences between them but, apart from some very early decisions, it is rare to find any analysis of the details of the offer. Indeed, it appears that there is only one case, the Canadian Roxy application, ${ }^{40}$ in which the Board has declined an application on the basis that negotiations have not proceeded far enough. In several other cases the Board seems to have been satisfied with very little in the way of bona fide negotiations on the part of the applicant. The role of the applicant is emphasized here since all that the applicant must establish is that reasonable offers have been made. It clearly need not demonstrate that both parties have been reasonable, for if that were the case a recalcitrant tract owner could continually frustrate the purposes of the legislation.

\section{The Canadian Roxy Application}

Canadian Roxy's 1992 application ${ }^{41}$ seems to be the only case in which the Board rejected an application on the basis of incomplete negotiations. The Board was able to reach this conclusion primarily because of its finding that the applicant had supplied erroneous cost information. As a result, several offers and counter-offers had not been fully explored. The application involved a concurrent production scenario. The applicant had drilled an oil well (the 6-30 well) in 1988 which was granted net gas-oil ratio penalty (GOR) relief ${ }^{42}$ until September 1990 when the intervenor, having drilled a gas

At least in the absence of a doctrine of "equitable pooling," the owners of the tract where the well was located would be under no common law obligation to share production with other tracts within the DSU; this is precisely why one needs an order or a pooling agreement. But see Lichacz v. Magna Petroleums Lid. (1993), 160 A.R. 193, aff d 162 A.R. 180 (C.A.) and discussed in Bankes, supra note 1 at 506-10.

42 See OGCR, supra note 9 , s. 10.050 and sch. 6. 
well in the same section, persuaded the Board to rescind the GOR penalty relief because of possible gas cap production at the 6-30 well. The record showed that the applicant had tried to dissuade the intervenor from applying for the rescission of GOR relief and that negotiations effectively terminated upon the intervenor making the GOR relief application. In those circumstances, the examiners felt justified in rejecting the pooling application and deferring issuance of the concurrent production approval until the issue of gas cap sharing was resolved. ${ }^{43}$

\section{Cases in Which the Board Has Been Satisfied by}

Evidence of the Course of Negotiations

In a 1978 decision, the applicant, which held the rights to the west half, entered into negotiations with a party that held an undivided interest in the east half. The applicant never entered into negotiations with any of the other tenants-in-common in the west half on the grounds that, until it commenced its pooling application, it did not know there were other owners. Nevertheless, the examiners felt that it was appropriate to continue with the application since they considered that nothing would be gained by requiring further negotiations. ${ }^{44}$

Other cases in which the Board has been satisfied by no negotiations, or superficial negotiations, include decisions in which part of the DSU is included in a unitization agreement. In those cases it appears that the tract owners conclude relatively quickly that it would be easier and more efficient to have the Board make a compulsory pooling order, rather than attempt to get the required consents (perhaps unanimous) to an amendment of the unitization agreement. The Board has acquiesced in this role. ${ }^{45}$

\section{Board Examination of Reasonableness}

In Universal Explorations (83) Ltd., ${ }^{46}$ PanCanadian (PCP) refused to agree to a pooling arrangement until the well operator had obtained "an acceptable gas purchase contract." ${ }^{\text {"47 }}$ PCP argued that until it knew the terms of the purchase contract it could not evaluate a pooling arrangement. Consequently, continued PCP, its refusal to pool was not unreasonable and therefore "it did not believe that there was a need for a pooling order.,48 The examiners rejected that argument and ruled that PCP's refusal was unreasonable, in part because PCP was not able to define what it meant by an "acceptable" gas purchase contract, and in part because a Board pooling order would provide that a tract's share of costs should come out its allotted production. ${ }^{49}$

Ibid. at 3.

Renaissance Resources Ltd., Compulsory Pooling, Amisk Area, Examiners' Report, Application 780637.

Tripet Resources, Compulsory Pooling, Nevis Field, Examiners' Report E 86-18; Gulf Canada Resources Ltd. supra note 25.

Universal Explorations (83) Ltd., Common Purchaser, Compulsory Pooling, Strathmore Belly River, Examiners' Report E 86-3 [hereinafter Universal].

Ibid. at 10.

lbid.

Ibid. at 12. 
The Board will not refuse an application on the grounds that drilling and completion will be sub-economic (because a tract owner in that position can elect to go penalty), ${ }^{50}$ nor will it decline an application on the grounds that another tract owner considers that underlying reserves could be recovered through other wells in the area. ${ }^{51}$ In some cases in which the distribution of reserves is uncertain, intervening tract owners have argued that the application should not be considered and granted until after the applicant has drilled its well. The Board has never accepted this argument which is inconsistent with a legislative scheme which speaks both to the situation of a well already drilled, and the issuance of an order prior to drilling. ${ }^{52}$

\section{No Agreement With Owners of the Corporeal Estate}

Most cases that come before the Board and which involve the owner of the corporeal estate rather than a lessee are cases in which the owner of the fee title of a tract is "missing or untraceable," or cases in which the working interest owners of separate tracts cannot agree on pooling terms. In rare cases, tract owners can be traced but simply refuse to lease the lands on any terms, or on the terms proposed. The Board will assume jurisdiction in those cases and order compulsory pooling. In one case the applicant, Andex Oil, ${ }^{53}$ offered to purchase the mineral titles of two tract owners for two lump sums but the owners refused, and refused also to participate in the drilling of a well. The examiners granted the order. There is no suggestion from the decision that the examiners conducted an independent examination of the reasonableness of the applicant's cash offer to purchase. Neither is there any suggestion that the examiners considered other solutions such as a cash bonus plus a royalty arrangement, based upon what the applicant had arranged with other parties.

In a 1977 decision, ${ }^{54}$ the Board heard evidence that the mineral owners in two tracts refused progressively more generous offers to lease (the final offer was a $\$ 15$ per acre bonus and a $162 / 3$ percent royalty) and concluded that a reasonable agreement could not be reached. The Board ordered compulsory pooling with each tract to share costs and production on an acreage basis. Again, there was no suggestion that the Board might impose a lease arrangement on the recalcitrant owners.

\section{OTHER REASONS FOR DENYING AN APPLICATION}

The Board will deny an application where an order would serve no useful purpose and perhaps interfere with the operational freedom of an existing licensee. This

5!

32

53

S4

Gulf Canada Resources Ltd., Compulsory Pooling, Bashaw Area, Examiners' Report E 95-12 at 5 [hereinafter Gulf Leduc Gas].

Chancellor Energy Resources Inc., Compulsory Pooling, Blood Area, Examiners' Report E 95-2 [hereinafter Chancellor Energy Resources].

Lorrac Energy Ltd., Compulsory Pooling, Pembina Field, Examiners' Report E 94-1 [hereinafter Lorrac Energy].

Andex Oil Co. Ltd., Compulsory Pooling, Twining Field, Examiners' Report, Application 780680, and Order No. P 47 (15 May 1979) [hereinafter Andex Oil].

Voyager Petroleums Ltd., Compulsory Pooling, Warwick Area, Examiners' Report, Application 770717. 
proposition is derived from the Board's Westburne Petroleum decision. ${ }^{55}$ In that case, the tract owner (WP) of the SW quarter sought a compulsory pooling order of the Glauconitic rights with production to occur through an existing well operated by PCP for production from a different zone. WP proposed that it be appointed as operator of the well. However, upon examining the evidence, the Board concluded that were it to make an order, it would allocate zero reserves to the SW quarter and, on that basis, decided that the application should be denied. Presumably, had the application been brought by PCP, the Board would have granted either a compulsory pooling order or a special spacing unit order. ${ }^{56}$

\section{SPECIAL CASES: CONCURRENT PRODUCTION POOLING ORDERS AND VERTICAL POOLING}

This Part discusses two special types of pooling application, first, a pooling application in the context of a concurrent production scenario and second, so-called "vertical" pooling.

\section{A. CONCURRENT PRODUCTION}

In the last ten years, the Board has faced a number of applications in which gas owners have endeavoured to use a compulsory pooling order to get a share of gas cap gas that is being produced by a designated oil well or on oil well spacing. In the typical case, the applicants have no interest in the DSU for the oil well but have an interest in a tract that forms part of the larger gas DSU. The Board has dealt with at least four such applications. ${ }^{57}$

The first concurrent production pooling application to come before the examiners was Suncor's 1987 Ghost Pine application. ${ }^{58}$ Suncor held the lease for the south half of section 31 and was the operator of a gas well. Opinac was the operator of an oil well in the north half of the section that had a history of gas production in excess of that which could be attributed to solution gas production. The examiners noted that resolution of pooling of the gas cap was linked to resolving issues of concurrent production. Even if successful in this pooling application, Suncor would still have to pursue its other application for concurrent production. ${ }^{59}$ The examiners granted the pooling application, and, in the course of doing so, made two useful rulings. The first

Westburne Petroleum \& Minerals Ltd., Compulsory Pooling, Long Coulee Field, Decision D 8620.

See discussion below at Part XVI, and see also Order No. P 113 (21 October 1993), Northstar Energy, Compulsory Pooling, Long Coulee Field, in which the Board granted an order allocating 100 percent of production to a tract covering three quarters of the section and 0 percent to the southeast quarter.

Canadian Roxy Petroleum, supra note 40; Suncor Inc., Compulsory Pooling, Ghost Pine Field, Examiners' Report E 87-18, and Order No. P 91 (24 February 1988) [hereinafter Suncor]; Order No. P 135 (9 November 1995), Canadian 88 Energy, Compulsory Pooling, Sylvan Lake Area (no Examiners' or Board Report) [hereinafter Canadian 88 Energy]; Gulf Leduc Gas, supra note 50 and Order No. P 130 (13 September 1995).

Ibid.

$59 \quad O G C A$, supra note 2 , s. 26(1)(e). 
was to reject Suncor's application that each company be appointed as operator of its well under the terms of the pooling order. The examiners ruled that the Act contemplated the appointment of a single operator and, in this case, appointed Suncor as the operator of the only licensed gas well in the DSU. Second, and linked to the first point, the examiners indicated that the terms of the pooling order should also bind any oil well "that produces gas in excess of solution gas from the pool." ${ }^{60}$ The order was granted on those terms. ${ }^{61}$

In a more recent decision, the Board seems to have been less concerned about the niceties of whether or not a single order could appoint different operators for different wells. Unfortunately for present purposes, this was a case, (on the application of Canadian 88 Energy Corp.) that the Board disposed of without the assistance of an Examiners' Report. Nevertheless, the following sections of Order P. 135 capture the nature of the pooling that was effected:

1. All tracts within Section 20 ... shall be operated as a unit to permit the production of gas or gas in excess of solution gas from all zones below the base of the Mannville Group through a well to be drilled in the North half or South-east quarter of the section (the subject well), and any oil wells in Section 20 which produce gas in excess of solution gas.

3. (1) Canadian 88 Energy Corp. shall be the Operator of the subject well and shall be responsible for the well and for all completing, producing and abandonment operations at the well.

(2) The Operator of any oil well drilled in Section 20 which produces gas in excess of solution gas shall be the party which drilled the well and this party will be responsible for the well and for all completing, producing and abandonment operations at the well. ${ }^{62}$

This decision goes beyond the Suncor case in several ways. First, it indicates that the Board will make an order of this nature even if the applicant has yet to drill its gas well. ${ }^{63}$ Second, the Board, in this instance, designated operators in the abstract for any oil well already drilled, or to be drilled in the future, that produced gas in excess of solution gas.

Order No. P 91, supra note 57 at paras. 1, 2.

Order No. P 135, supra note 57.

Quaere, what would happen if the applicant failed to drill its well? Would the balance of the order stand for any existing oil wells that were producing gas in excess of solution gas? At the very least the Board would have the jurisdiction to review the Order of its own motion; see supra note 24. More importantly, does an applicant need to agree to drill a well at all in this type of scenario? See s. 72(2)(f) of the OGCA, supra note $2-$ is this paragraph jurisdictional? 
The third example is the 1992 Examiners' Report on Canadian Roxy's application in the Manyberries Field. ${ }^{64}$ The facts of this application have already been outlined. ${ }^{65}$ CanRoxy applied for approval of concurrent production and a compulsory pooling order for gas production from the 6-30 well. The examiners were prepared to approve the application for concurrent production but decided that a pooling order should not be granted because CanRoxy had not provided accurate information. In the circumstances, given the inevitability of gas cap production from the 6-30 well, the examiners ordered the 6-30 well suspended pending resolution of the sharing of gas production.

In the fourth recent concurrent production decision, the examiners granted a compulsory pooling order to Gulf for gas cap production from the 16-9 well. The well was originally completed as a Leduc oil well but Gulf proposed to recomplete it as a gas well. The examiners ${ }^{66}$ went to pains to emphasize that the pooling order was limited to gas production that was in excess of the solution gas. They explicitly rejected an argument from a party with an interest in a different quarter section that the pooling order also apply to any oil that might be produced. ${ }^{67}$

These cases merit attention as a way of dealing with the equity problems that arise when concurrent production is authorized, or in those situations in which an oil well is producing solution gas. The oil well owner may not own all of that gas if the oil and gas rights have been severed, ${ }^{68}$ but even if the rights have not been severed, tract owners within the gas DSU, but outside the oil DSU, may have an interest in some of that gas production (the gas cap gas). Compulsory orders may be used to address these problems in the event that the oil well owners decline to negotiate on reasonable terms. One of the difficulties that the parties will encounter in the course of negotiations is the question of equalization of costs for a well that is drilled primarily as an oil well. On what basis should these costs be shared with the gas owners? This issue was raised in some of the decisions discussed above and ignored in others. ${ }^{69}$ This question is returned to in the more general treatment of equalization below. ${ }^{70}$

\section{B. VERTICAL POOLING}

The problem of pooling is usually only conceptualized from an areal or horizontal perspective; pooling is thought of as a mechanism for sharing production and costs amongst those owners that have rights to different tracts within the DSU. There are two operating assumptions behind this conceptualization. First, it is assumed that if there has been a severance of shallow and deep rights within the DSU, then the shallow

Supra note 40.

See above, text accompanying notes $40-43$.

Supra note 50.

Ibid. at 4.

Borys v. C.P.R. (1953), 7 W.W.R. 546 (P.C.); Prism Petroleum Ltd. v. Omega Hydrocarbons Ltd., [1994] 6 W.W.R. 585 (C.A.); J.M. Pasieka \& N.G. Cameron, "Ownership of Evolved Gas in Split Title Situations" (1991) 29 Alta. L. Rev. 19.

The matter was dealt with in Canadian 88 Energy, supra note 57, and Gulf Leduc Gas, supra note 50, but not in Suncor, supra note 57.

See below at Part $X$. 
rights owner has the exclusive rights within the DSU to all pools lying above the severance point, and the deep rights owner has the exclusive right to all pools lying below the severance point. Second, it is assumed that no situation should arise where a pool extends both above and below the shallow rights/deep rights separation line.

But what if these operating assumptions are incorrect? What if a division of mineral rights between shallow and deep zones severs the mineral rights through the vertical axis of a pool? Does the concept of pooling and the possibility of compulsory pooling apply? The answer, in principle, is yes.

\section{Identification of the Problem}

The problem arises most commonly in Alberta as a result of the severance of deep rights under the terms of the Mines and Minerals Act. ${ }^{71}$ Under that Act, the Crown, during the 1980s, resumed title to the deep rights below the deepest producing horizon of all Crown leases. ${ }^{72}$ Since then, Crown leases have only been continued at the end of the primary terms down to those horizons that are established, to the satisfaction of the Minister, to be capable of production. ${ }^{73}$ The Crown and the ERCB issued a joint information letter (IL) on the problems created in $1988 .{ }^{74}$ The IL noted that:

In some situations, the contact between a shallow rights agreement and a deeper rights agreement may occur within the vertical dimension of a pool. When evaluating an application for lease continuation, the Alberta Department of Energy makes every effort to correctly identify the zones present in the entire pool to avoid the splitting of rights in a production entity within a pool.

There may be situations, however, where information is limited or where pools similar to the above examples [the IL provided a list of examples including Zama/Keg River] have not been discovered or their reservoir continuity has not been demonstrated at the time of lease expiry. In such situations, the shallow and deeper rights lessees would be clearly entitled to drill one or more wells into the two separately leased zones and produce the leased minerals. It should be noted, however, that where subsequent pressure and production data, or well bore information, confirms that the leased minerals fall within a common pool, production would be subject to ... ERCB legislation.

In the event that separate pools cannot be established or maintained, a mineral owner could request that the ERCB invoke the provisions of Section 72 of the Act requiring a pooling of the rights. In such situations, the department and the ERCB would prefer that the lessees reach their own voluntary pooling agreement. 
The IL also noted that the Board had an established jurisdiction, per s. $21 O G C A$, to designate pools and to resolve disputes as to the application of a zone or pool designation. $^{75}$

The pooling problem arises once it is determined, either by agreement between the parties, or as a result of a Board designation order, that wells drilled by the deep and shallow rights lessee have the capacity to produce from the same pool, within the same DSU. The Board will not allow both to produce ${ }^{76}$ and there is therefore a need, as in the case of horizontal pooling, to allow each a share of production rather than allocating the entirety of the production to one or other of the lessees.

The claim in the IL that the Board has the jurisdiction to make a compulsory pooling order in these circumstances is supported by the language of s. 70 of the $O G C A$. There are separate tracts within the spacing unit (along the vertical axis of the zone) and the lessee of each tract is an owner of a tract within the meaning of ss. 70 and 72 since each lessee "has the right or an interest in the right to drill for, produce and dispose of any oil or gas from the tract." Consequently, if negotiations fail, either lessee could apply to the Board for an order under s. 72 or s. 73. In recent litigation, however, the parties have questioned whether the Board's jurisdiction under both ss. 21 and 72 of the $O G C A$ is an exclusive jurisdiction, or whether the courts have concurrent, or indeed a more extensive jurisdiction to make retrospective and prospective orders in relation to these matters.

\section{Gulf Canada Resources Ltd. v. Ulster Petroleums}

Briefly, the facts of Gulf Canada Resources Ltd. v. Ulster Petroleums ${ }^{78}$ are as follows. Gulf claimed a royalty down to the basement under the terms of a farmout of

$O G C A$, supra note 2 , s. 21 . The section provides:

21(1) The Board may, by order,

(b) designate a pool by describing the surface vertically above the pool and by naming the geological formation, member or zone in which the pool occurs ...

(e) designate any stratum or sequence of strata as a zone, either generally in respect of any designated area or any specified well or wells.

(2) If dispute arises in the application of a pool or zone designation made by the Board, the dispute shall be referred to the Board and its decision on it is final.

For a recent decision see Hillcrest Resources Ltd., Application to Determine the Base of Mannville in Township 40, Range 5, West of the 5th Meridian, Decision D 95-10. the matter:

(3) No person shall apply for a licence for a well for the purposes of obtaining production from the same pool as that from which another well is obtaining production in the same drilling spacing unit unless the Board, if it believes special circumstances warrant it, authorizes the making of the application or unless the wells are required for the operation of an experimental scheme that has been approved by the Board. 
a 1969 Crown petroleum and natural gas lease. Rights below the base of the Muskeg reverted to the Crown in 1983. The Crown subsequently re-leased the lands to a third party and then re-acquired and re-leased them, this time to the same working interest holders that held the shallow rights. The defendants drilled two wells under the terms of this second lease, the 12-36 and the 4-36 wells. Both were originally classified by the ERCB as Virgo Keg River (deep rights) wells. In 1992 the ERCB redesignated the 12-36 well as a Virgo Muskeg pool well (shallow rights). There has been no redesignation of the 4-36 well.

Gulf commenced an action for unpaid royalty in relation to production from both wells from the date that they commenced production. The action was defended on the basis that questions relating to:

a. the determination of from which pool a well is producing, and,

b. the allocation of production to that well,

are both matters exclusively within the jurisdiction of the Board. Those contentions have been rejected thus far on a motion to strike certain portions of the statement of claim, and to determine preliminary points of law. The court rejected these contentions, notwithstanding the privative clauses in the $O G C A^{79}$ and the Energy Resources Conservation $A c t,{ }^{80}$ largely on the basis that no order of the Board, including a compulsory pooling order or a pool designation order, could have a retrospective effect. By contrast, a judicial decision might have a retrospective effect and could therefore deal more fully with the differences between the parties.

The case is on appeal. The case does raise serious issues ${ }^{81}$ as to the relationship

$O G C A$, supra note 2 , ss. $21(2)$ and 86.

Supra note 5, s. 45.

For example, the decision casts doubt upon what could be called the constitutive effect (or property effect) of Board pool designation orders. A Board order establishing a pool has a legislative character that binds the whole world, not just those persons that happen to have sought the order. The term "order" is not necessarily indicative of a quasi-judicial or an administrative function rather than a legislative function. See the Interpretation Act, R.S.A. 1980, c. I-7 where the term "regulation" is defined to include an order enacted pursuant to a power conferred under the authority of an Act. That definition is, in turn, incorporated by reference in the Regulations Act, R.S.A. 1980, c. R-13, s. 1(1) with the proviso that the regulation must be of a "legislative nature." All regulations and orders of the Board pursuant to the $O G C A$ (except orders pursuant to ss. 10(1), 47 and 48) are exempt from the filing requirements of the Regulations Act (Alta. Reg. 282/89, s. 20(b)). In Camac Exploration Lid. v. Oil and Gas Conservation Board of Alberta (1964), 47 W.W.R. 81 (S.C.) the court assumed that the rules of natural justice applied to an application for a special spacing unit and target area order. In practice, s. 29 of the ERCA, supra note 5 , accords the Board the discretion to make an order without notice unless the Board concludes that its decision may adversely affect the rights of a person at which time it shall give notice of the application. See also Wiswell v. Metropolitan Corporation of Greater Winnipeg, [1965] S.C.R. 512; and McIntyre Ranching Co. v. Cardston 6 (1983), 28 Alta. L.R. (2d) 206 (C.A.) indicating that bylaws affecting particular parcels may be quasi-judicial in nature.

Ulster, supra note 78 , is less far-reaching insofar as it suggests that a court could determine on what amount of production from the pool the royalty needed to be paid. Mesa Operating Limited 
between the courts and the Board, but its more general importance for present purposes lies in its confirmation that the Board cannot issue retrospective pooling orders. This article shall return to this point below. ${ }^{82}$

Research and inquiries at the Board indicate that the Board has yet to receive a compulsory pooling application in the context of vertical pooling. ${ }^{83}$

\section{THE ELEMENTS OF THE ORDER: THE ALLOCATION OF PRODUCTION}

\section{A. PRESUMPTION IN FAVOUR OF ACREAGE ALLOCATION}

Section $72(4)(c)$ of the Act requires that any order shall provide:

(c) for the allocation to each tract of its share of the production of oil or gas from the drilling spacing unit unless it can be shown to the Board that that basis is inequitable.

Section 72(4)(c) creates a clear presumption in favour of an acreage-based allocation of production rather than a reserves basis. It seems equally clear that the onus is on the party who wishes to contend for a reserves-based allocation. The examiners put it this way in one application:

Firstly, the examiners believe that the subsection establishes a presumption that if an order is issued, the allocation will be on an area basis. Secondly, that the presumption may be rebutted so as to require an allocation on a reserve basis, but in order to do so, the onus is on [a party] to show the Board that an allocation on an area basis is inequitable. It is clear that there is no burden on [a party] to demonstrate in a compulsory pooling order that an allocation on an area basis is equitable. ${ }^{\text {M }}$

The Board and its examiners require solid evidence before the presumption will be rebutted. ${ }^{85}$ The Board will use geological, geophysical, and engineering data, and

Partnership v. Amoco Canada Resources Ltd. (1994), 149 A.R. 187 (C.A.) [hereinafter Mesa], relied upon in Ulster, provides some support for that function, which, in the present case, would be presented as a function of interpreting the contract between the parties. Only the Board can make a compulsory pooling order and a pool designation order (both statutory creations (Heller v. The Registrar, Vancouver Land Registration District, [1963] S.C.R. 229)), but the court can determine upon what production the parties agreed to make royalty payments. See below at Part XII.

Interview with K. Fisher, AEUB, Calgary (22 October 1996); there have been some inquiries but, to date, all issues have been resolved by private agreement.

Application by Amoco Canada Petroleum Company Ltd., Compulsory Pooling, Deadwood Field, Examiners' Report E 83-3 at 13 [hereinafter Amoco]. Quaere, in the case of a missing or untraceable owner does the Board owe any duty to those tract owners to satisfy itself that an acreage allocation is equitable?

In Pembina Resources Ltd., Compulsory Pooling, Brazeau River Field, Examiners' Report E 91-6 [hereinafter Pembina Resources], the examiners agreed that geologic date that tended to show that the pool was only situated in the west half of the section was "interpretational" and did not justify pooling on a reserves basis. In Suncor Inc., supra note 57, the examiners rejected a reserves distribution even though there was data from two wells in the DSU. This was a case in which the characteristics of the reservoir vary within short distances and even though neither party believed that the pool extended throughout the DSU the data was "so highly interpretive that it is not 
isochronal mapping, to assist it in developing an opinion as to the distribution of reserves within the DSU. ${ }^{86}$ Seismic data is most often too interpretational to be of much assistance in allocating reserves, while well data will usually be much more reliable and meaningful. Relevant wellbore parameters include net pay, porosity, and water saturation. ${ }^{87}$

The appropriate standard of proof that an applicant must meet before the Board should be persuaded to depart from an acreage allocation is that of the balance of probabilities. Standard of proof was the subject of some comment from Kerans J.A. in Mesa v. Amoco. ${ }^{88}$ In that case Amoco contended that the trial judge had erred by applying a lower standard of proof (a balance of probabilities) than that applied by the Board which Amoco characterized as "a high degree of certainty." Kerans J.A. rejected that characterization indicating that, in his view, the Board applied a standard of balance of probabilities. ${ }^{89}$

\section{B. RESERVES ALLOCATION}

If the Board determines that an allocation on a reserves basis is appropriate, the Board still has to decide how to allocate the reserves between the tracts. The Board has used a variety of techniques to effect this allocation. ${ }^{90}$ In the Mission Resources decision, the examiners had before them wellbore data from two wells. That data supported Mission's contention of thicker tested gas pay in the north half of the section. The panel developed a set of relevant wellbore parameters from the two wells to arrive at a hydrocarbon pore volume for the pay bearing sands for each of the two wells. The fraction that each bore to the total established the allocation. ${ }^{91}$

possible to use it with any high degree of certainty in determining the reserves of gas in place under each half section." Thus acreage-based pooling would not be inequitable (ibid. at 8). In Ironwood Petroleum Ltd., Bearspaw Petroleum Ltd., Compulsory Pooling, Drumheller Field, Examiners' Report E 96-12 [hereinafter Ironwood Petroleum] the examiners noted at 8-12 that uncertainties as to the distribution of reserves meant that pooling had to be on an area basis. Mission Resources, supra note 33.

Ibid.

Mesa, supra note 81.

Ibid. at 194-95. Kerans J.A. noted that: "[U]nsurprisingly, they do not articulate a burden of proof and adjectives are loosely used." With respect, the issue is not who has the onus or burden of proof; the issue is the appropriate standard. The standard is the balance of probabilities but as to what? The person seeking a compulsory pooling order must establish, on the balance of probabilities, that areal based pooling "is inequitable." For a useful discussion of standard and burden in a technical oil and gas statutory context see Barry J.'s judgment in Re Petro-Canada v. Canada Newfoundland Offshore Petroleum Board (1995), 127 D.L.R. (4th) 483 (Nfld. S.C.) [hereinafter Re Petro-Canada]. See also Gannon Bros. Energy Lid. v. Alberta Energy and Utilities Board and Ranger Oil Ltd. (18 January 1996), (Alta. C.A.) [unreported]. The court per Kerans J.A. noted that the standard of proof that the Board was to apply in determining whether two wells were producing from the same pool was that of the balance of probabilities and that that was the test that the examiners had applied in the decision appealed from, even though they had spoken in terms of "conclusive evidence."

Sometimes the Board provides very little in the way of supporting reasoning for its allocation. See, for example, Elmtree Oils Ltd., Compulsory Pooling, Campbell-Namao Field, Examiners' Report E 84-3 [hereinafter Elmtree].

Mission Resources, supra note 33. 
Sometimes the Board uses its judgment to determine a probability for the contentions of each of the parties. It then takes a rough average of the two probabilities to arrive at an allocation. An example will illustrate this point. In a 1981 application by Suncor, the facts were as follows. ${ }^{92}$ Suncor's gas unit held the gas rights in the west half. McBride held the NE quarter rights as the freehold owner and Bow Valley was the lessee of the SE quarter. Suncor settled with McBride but Bow Valley rejected Suncor's offer of a 10 percent working interest or a 2 percent gross overriding royalty. The examiners accepted that reserves-based pooling was justified on the basis that there were significant variations in reservoir quality between the west and east halves. The examiners took into account evidence of lithological changes and water saturation data in reaching that conclusion.

Suncor argued before the examiners that there were no reserves underlying the SE quarter. The examiners gave that contention a 75 percent probability. Bow Valley argued that some 20.7 percent of the reserves underlay the SE quarter. The examiners considered that that contention had a 25 percent probability. Combining the two (i.e. taking a 25 percent probability that 20 percent of the reserves underlay the SE quarter) the examiners recommended a 5 percent allocation to Bow Valley which was only half what it had been offered by Suncor. The examiners did not recommend an allocation for the NE quarter, choosing to rely instead upon Suncor's assertion that it had an agreement with McBride. ${ }^{93}$

Where the examiners cannot arrive at a probability factor they will simply use their best judgment in their evaluation of the existing data to determine what "seems equitable." In one older decision ${ }^{94}$ Voyager had presented evidence that there was no oil underlying LSDs 9 and 16 but had nevertheless offered the owner a 10 percent acre bonus and a 20 percent royalty as one of a series of 7 leasing attempts over a period of four years. The examiners rejected Voyager's application for a 0 percent allocation deciding instead to allocate 3.125 percent to LSDs 9 and 16; a mere 25 percent of the acreage allocation.

In many cases, the Board confronts significant uncertainty as to the downhole distribution of reserves, and in one of those cases, the Board held that the applicant bears some burden to resolve the uncertainty through its choice of well location within the DSU. In effect, the Board claimed the right to draw an adverse inference as to the distribution of reserves in the DSU if the applicant elected to drill the well in a location most favourable for recovering reserves, but the least useful in terms of providing information on the distribution of reserves. Such was the case in the Board's treatment

Suncor Inc., Compulsory Pooling, Medicine River Field, Examiners' Report E 81-4.

This suggests that the Board will limit the scope of its decision as much as possible. If some tract owners are able to agree as to how they will divide their allocation amongst themselves, the Board will not interfere.

Compulsory Pooling, Warwick Area, Examiners' Report, Application No. 8835 (22 December 1975). 
of Gulf Canada's Cheddarville Area application in $1986 .{ }^{95}$ Esso held the rights to the west half and Gulf held the rights to the east half. Gulf proposed to drill a well in the west half. The evidence before the Board was equally balanced. ${ }^{96}$ Some of the evidence tended to show that the pool didn't extend into the east half while other evidence suggested that the pool did. The only way of determining this issue with any certainty was by drilling a well. However, a well drilled in the west half would reveal nothing about the distribution of the reserves underlying the section. Consequently, the Board devised a sharing formula that accorded Gulf a progressively larger proportion of production the further east the well was drilled. ${ }^{97}$ This is clearly one way in which to deal with the uncertainty. The approach seems justifiable given the particular gaps in the information available to the Board in this particular case. ${ }^{98}$

\section{ELEMENTS OF THE ORDER: SUBSTANCES AND ZONES}

The decisions of the Board and its examiners show that there have been two contentious issues related to the scope of the order. The first relates to the zones subject to the order. The second arises in the context of concurrent production applications and relates to the substances that are the subject of the order.

95 Gulf Canada Corporation, Compulsory Pooling, Cheddarville Area, Decision D 86-14, affd by Gulf Canada Corporation v. Energy Resources Conservation Board (8 October 1987), (Alta. C.A.) [unreported] [hereinafter Gulf Cheddarville].

* Since Gulf had actually proposed allocation on an acreage basis, the statement by the Board ibid. at 3 of its decision that "it cannot find evidence to support one interpretation more than the other and therefore concludes that each is plausible" comes dangerously close to ignoring the presumption contained in s. 72(4)(c). However, if this sentence is read in the broader context of the Board's overall disposition of the application it can safely be concluded that the Board did indeed think that acreage-based allocation was inequitable but that the evidence was not conclusive on distribution. On appeal to the Court of Appeal, leave was granted on the following question of law:

Based on the Board's findings in this case, did the Board err in law in finding that an allocation of reserves on an areal basis pursuant to section $72(4)(\mathrm{c})$... would be inequitable.

The notes of Jill Page, counsel to the Board, (on file with the Legal Department of the EUB) summarize Stevenson J.'s judgment for the court as follows:

This is not a question of law. The Board determined that there were proven reserves in the west half of the section. The Board found that the reserves in the east half of the section were unproven and uncertain. On those findings the Board determined it would be inequitable to apportion on an acreage basis. Even if there was an onus on Esso, Esso has proven it has the reserves on its half of the section and that there is uncertainty that Gulf has the reserves. The Board did not err in law in its decision.

Even this brief account suggests that the Court accorded considerable deference to the Board's finding. On its face it appears as if the Board is entitled to make a reserves-based apportionment where it finds that some reserves are proven and some are unproven. Ibid. at 3.

98 In other cases the Board has rejected the arguments of intervenors that the applicant resolve the uncertainty by first drilling a well: see Lorrac Energy, supra note $\mathbf{5 2 .}$ 


\section{A. ALL ZONES DOWN TO THE BASE OF A SPECIFIED OR THE SPECIFIED ZONES?}

Many applicants ask the Board to make an order for all formations down to a particular target formation. ${ }^{99}$ The Board's practice is not entirely consistent on this point ${ }^{100}$ but whenever another party takes an objection, the Board invariably rules that the pooling order must be confined to "those formations that have been shown to require compulsory pooling and are believed to be capable or being made capable of production." 101 In these cases the Board will stipulate for which formations the order will be granted. In cases where (presumably) no objection is taken, it is not unusual to find orders in the form of "all zones below the base of the Mannville Group"; ${ }^{102}$ "all zones to the base of the Nisku"; ${ }^{103}$ or "all zones to the base of the Mannville." 104

The Board's refusal to grant an application in broad terms whenever an objection is taken is consistent with the combined effect of s. 72(2)(b) and s. 72(3) of the OGCA. Section 72(2) requires the applicant to state "(b) the formation to which he proposes to drill or from which he proposes to produce" while subs. (3) provides that:

The Board may, with the approval of the Lieutenant Governor in Council, order that the tracts within the drilling spacing unit be operated as a unit with respect to the formation referred to in subsection (2)(b). ${ }^{105}$

\section{B. THE POOLED SUBSTANCES}

The typical pooling order will usually specify a pooling for the purposes of producing gas or oil. ${ }^{106}$ Greater specificity may be required in a concurrent production scenario. In Gulf's Leduc Gas 1995 pooling application the intervenor argued that if Gulf was seeking to equalize the entire costs of drilling a well that had initially been drilled as a oil well, then it was only appropriate that all substances produced from the

See for example Gulf Fenn-Big Valley, supra note 6.

If no objections are made, the Board will approve the order down to a particular horizon (e.g. City of Medicine Hat, Amend Order P 37, Medicine Hat Field, Examiners' Report E 85-5 “all zones down and including the Second White Speckled Shale" [hereinafter Medicine Hat]).

Gulf Fenn-Big Valley, supra note 6 at 6; Ashlu, supra note 5 at 3; Chancellor Energy Resources, supra note 51 at 5; Pembina Resources, supra note 85 at 5.

Order No. P 135, supra note 57.

Order No. P 132 (23 November 1995), PB Resources Inc., Compulsory Pooling, Viking-Kinsella Area (see PB Resources, supra note 38).

Order No. P 125 (25 May 1995), Benson Petroleum Ltd., Compulsory Pooling, Viking-Kinsella Area.

The Board's practice is therefore legally correct but it is not difficult to imagine situations in which the practice may cause some hardship, especially where the applicant wishes to drill its well in a tract of the DSU in which it does not have a property interest. The Board will grant this type of application (see below, text accompanying notes $121 \mathrm{ff}$ ) but if the order is formation-specific it must follow that the operator can only carry out tests on those formations that are the subject of the order. If the operator tests other formations it will be a trespasser. If the well is drilled in a tract in which the operator has an interest, the problem is resolved for the operator can test any formations and if it proves productive may apply to the Board for an amendment of its order.

See for example Order No. P 125: "all tracts ... to permit the production of gas" (supra note 104). 
well be subject to the pooling order even though the intervenor had no oil rights in the oil DSU. ${ }^{107}$ The Board rejected that argument as well as Gulf's two alternative submissions that only gas production in excess of $1800 \mathrm{~m} 3 / \mathrm{m} 3$, or twice the solution GOR, should be the subject of the pooling order. The examiners thought that these proposals would exclude some gas cap gas from being pooled. The examiners recommended that all gas in excess of solution GOR should be pooled. ${ }^{108}$ Similarly, in the examiners' earlier decision in Suncor's application, the examiners suggested that pooling should apply to all gas cap production. Identification of this gas should be "based upon Board-established solution GOR for the pool."109

Any gas produced from any oil well in section 31 in excess of that which would be expected, based upon the established solution GOR, would be considered to be gas-cap gas and therefore subject to the sharing arrangements specified in the compulsory pooling order. ${ }^{110}$

\section{ELEMENTS OF THE ORDER: APPOINTMENT OF THE OPERATOR}

This Part deals with (1) the appointment of the operator and (2) the rights and obligations of the operator under the Act and under the terms of the Board's standard form pooling order. Section $72(2)(4)(b)$ of the $A c t$ requires that an order shall provide:

for the appointment of an operator to be responsible for the drilling, operation or abandonment of the well whether drilled before or after the order.

The appointment of an operator is not usually a contentious matter. In the ordinary course, the applicant for the order will be appointed as the operator for a well that it has drilled on its own tract of the pooled lands, or that it proposes to drill on its own tract. The issue has proven to be more contentious in four scenarios: (1) in the context of concurrent production, (2) in the context of multiple completions where an applicant proposes to take over an existing well operated by another party and complete the well in the zone that is the subject of the pooling application, (3) in the context of cases in which the applicant seeks to drill a well on a tract in which it has no interest, and (4) in the context of cases in which there is more than one well within the DSU that is capable of producing the pooled substances, and the examiners need to select one well for the purposes of the order.

\section{A. CONTENTIOUS CASES}

\section{Concurrent Production}

The problem of appointing an operator has already been discussed in the context of concurrent production where there may be more than one well capable of producing the 
pooled substances."' In the Suncor application the examiners stated that the Act only allowed them to appoint one operator for the purposes of a pooling order but also permitted them to issue an order binding production of the pooled substances from all wells in the DSU. ${ }^{112}$ In the Canadian 88 Energy decision the Board took the step that it declined to take in the Suncor application and appointed, potentially, multiple operators for different wells. ${ }^{1 / 3}$

\section{Multiple Completions}

In the Penn West application considered by the examiners in $1995,{ }^{114}$ the issue of the appointment of an operator was contentious. Penn West held the rights to the entire DSU in which the well had originally been completed. It now proposed a dual completion in a different zone in which it had only the rights to the east half. The well had been drilled in the west half. Both Penn West and Norcen (the owner of the west half rights) applied to be appointed as operator. Penn West noted that it was already the operator and licensee of the 6-12 well (SE quarter) while Norcen noted that it was the major working interest in the area and currently operated two other wells in the pool. The examiners preferred Penn West's application. ${ }^{115}$ A somewhat different set of facts came before the Board in the earlier Westburne application. ${ }^{116}$ In that case, Westburne (which held the rights to the SW quarter) applied to be appointed as operator for a dual completion attempt for an existing well drilled and producing from a deeper zone in LSD 10. This well was operated by PanCanadian. The Board rejected the application on the basis that it was not prepared to accord any allocation of production to the SW quarter. The Board went on to say that while it was not necessary to rule on Westburne's operatorship application:

The Board, however believes it desirable to comment that it questions its ability under s. 72 of the Oil and Gas Conservation Act, given other provisions of the Act, to appoint a party the operator of the well when that party has no direct interest in the well. The Board would urge an applicant to address this issue or consider alternative solutions under the existing legislation. ${ }^{117}$

The Board did not elaborate on what were the other provisions of the Act that it had in mind, or what might be the alternative solutions, but its subsequent decision in the Durish case ${ }^{118}$ provides some guidance.

III See above, text accompanying note 59.

112 Suncor, supra note 57 at 6-7.

$113 \quad$ Supra note 57.

114 Penn West Petroleum Ltd., Compulsory Pooling, Saddle Hills Field, Examiners' Report E 95-3 [hereinafter Penn West].

Ibid. at 5 . The examiners gave no reasons for this decision other than to note that Penn West was the current licensee and operator of the well.

Supra note 55.

Ibid. at 3.

Victor R. Durish and Seascape Oil and Gas Ltd., Assignment of Pipeline Licence, Compulsory Pooling and Transfer of Well Licence, Malmo Field, Decision D 90-2 [hereinafter Durish]. 


\section{No Interest in the Tract}

In Durish, the Board was faced with competing well licence transfer and pooling applications $^{119}$ for a DSU in which there was already an existing well capable of production on the NW quarter. The Board preferred Durish's application on the basis that Durish had a 100 percent interest in the NW quarter and that the other applicant was not entitled to a transfer of the licence since it did not have the rights to produce from that part of the DSU as required by s. 13 of the Act. ${ }^{120}$ Perhaps this was the section of the Act that the Board had in mind in Westburne, but if so, there must be a flaw in the reasoning because the pooling order itself, if granted, will accord the right to produce from anywhere on the DSU. Indeed, the Penn West case above is illustration enough of that as are the cases in which an applicant wishes to drill its well on a tract within the spacing unit in which it has no proprietary interest.

There are several instances in which the Board has authorized an applicant to drill and complete a well on a tract within the spacing unit in which the applicant has no interest. These decisions include the Gulf Cheddarville application discussed above ${ }^{121}$ and also a more recent decision on an application from Lorrac Energy. ${ }^{122}$ In that case Lorrac held the mineral rights to the SE quarter of section 31 and Kerr-McGee held the rights to the balance of the section. Lorrac applied for a compulsory order allowing it to drill a well directionally from a surface location in LSD 1 in the SE quarter of section 1 of the adjacent township to an on-target bottom-hole location in LSD 13 in the NW quarter of section 31. Lorrac argued that the presence of a river and more favourable tie-in options justified the location. Kerr-McGee objected to the application and argued that Lorrac should first drill an on-target well on its own tract and then apply to pool. The Board rejected that contention and granted the application with Lorrac as operator. ${ }^{123}$

In exceptional cases, the applicant may ask that another party be appointed as operator of an existing well, or a well still to be drilled. It is easy to see how this may occur in a concurrent production scenario, but it also occurred on the unusual facts of Amoco's 1983 Deadwood Field application. ${ }^{124}$ Neither party objected to the appointment of the current licensee as the operator under the pooling order.

For one other case in which the Board has dealt with a pooling and licence transfer situation see PB Resources, supra note 38.

Ibid. The examiners also recommended a reserves allocation with 20 percent allocated to the SE quarter; in this case, unlike Cheddarville, supra note 95, the examiners did not further "penalize" the applicant for failing to chose a location that would add to the examiners knowledge of the distribution of reserves in the spacing unit (see above, text accompnaying note 95 ). 


\section{Choice of Wells}

In rare cases, in addition to appointing an operator, the Board will be asked to choose which of potentially several wells should be authorized to produce the pooled substances. This may occur in the concurrent production scenarios discussed above, but the question may also arise in more conventional settings. A case in point is the examiners' recent decision in Ironwood Petroleum Ltd. ${ }^{125}$ The facts are as follows. The gas rights in section 18 were divided into 2 tracts, the NW quarter and the south half and NE quarter. Within the two tracts the allocation of rights differed between the two zones (the Belly River and Basal Quartz) that were the subject matter of the pooling application. Bearspaw had an interest in the NW quarter of the two zones; Ironwood had an interest in all tracts except the NW quarter of the Belly River. There were three wells within the section: (1) the 14-18 well licensed to Bearspaw, drilled in 1982 in the NW quarter, and alleged to be capable of production from both the Belly River and Basal Quartz zones; (2) the 2-18 well licensed to Ironwood, drilled in 1994 in the SE quarter, and capable of production from the Basal Quartz; and (3) the 11-18 well, licensed to Ironwood, drilled in 1995 in the NW quarter, and capable of production from the Belly River. On those facts, both Ironwood and Bearspaw brought competing pooling applications for both zones. Ironwood sought to be appointed as operator of the 11-18 well for production from the Belly River Group, and appointed as operator of the 2-18 well for production from the Basal Quartz. Bearspaw sought to be appointed as operator of the 14-18 well for production from both zones.

In deciding which well should be permitted to produce from each zone under a pooling order, the examiners concluded that they should give primary consideration to paragraph 4(a) of the Act and the Board's duty "to effect the conservation of, and to prevent waste of, the oil and gas resources of Alberta." Then, following an examination of the production tests conducted at each well, the examiners concluded that the tests conducted at the 14-18 well were unreliable. ${ }^{126}$ Consequently, the Examiners recommended approval of the application of Ironwood and denied that of Bearspaw.

\section{B. RIGHTS AND OBLIGATIONS OF AN OPERATOR WITH RESPECT TO PRODUCTION}

What are the rights of the operator and other tract owners with respect to production and the sale of production? Does a tract owner have the right to take in kind? Does a tract owner have the right to require the operator to market its production? These issues are dealt with in s. 72(4)(c) of the Act and the terms of the individual orders. The Act provides that an order must make provision: note. In both cases there is an issue as to equalization costs. If each party has a well that is capable of production from the pooled zone should either party be required to contribute to the costs of drilling the other well? 
(e) for the sale by the operator of any oil and gas allocated to a tract under clause (c) when the owner of it does not take or dispose of that production and for the deductions to be made by the operator out of the proceeds of sale.

Clause (c) provides for an allocation of production, not an allocation of the proceeds of production. Reading clauses (c) and (d) together it appears that a tract owner has the right to take in kind. It is also clear that a tract owner has the right to require the operator to market its production. Both issues are dealt with in the typical pooling order in a fashion that provides some protection to the operator who, after all, lacks the usual panoply of remedies available to an operator under the terms of the CAPL form including the operator's lien. ${ }^{127}$

The standard form of order provides that a tract owner may take in kind, or direct the disposition of its share of production, subject to a series of conditions. ${ }^{128}$ First, an owner of a tract may only make the election subject to two other clauses of the typical order: (1) the operator's right to sell the tract owner's share of production if the tract owner has failed to pay its share of operating expenses for any month within 15 days of being billed, ${ }^{129}$ and (2) the operator's right to sell the tract owner's share while the tract owner is still in a penalty position. ${ }^{130}$ Second, a tract owner must give the operator adequate notice of its intention to take in kind. ${ }^{131}$

The obligations of the operator under the standard form include the obligation to market the gas of tract owners that do not elect to take in kind. ${ }^{132}$ The obligation is typically framed in Board orders as an obligation to sell at "not less than" the current price in the field. ${ }^{133}$ In one case, an intervening tract owner argued that the operator should be required to account on the basis of the "higher of the operator's gas contract price and the price in the field." 134 The examiners rejected that contention indicating that they "do not consider it appropriate to specify any other conditions respecting gas

See the standard form operating procedure in use in western Canada published by the Canadian Association of Petroleum Landmen (CAPL). The most recent version of the form is the CAPL 1990 form. On this point see CAPL 1990, para. 505, and see Novalta Resources Ltd. v. Ortynsky Exploration Ltd, [1994] 6 W.W.R. 484 (Alta. Q.B.) [hereinafter Novalta] dealing with an earlier iteration of the CAPL form. Order No. P 145 (19 September 1996), Talisman Energy Inc., Compulsory Pooling, Clair Field, s. $6(1)$.

Ibid. and s. 7.

Ibid. and s. 8.

131 Ibid., s. 6 stipulates a thirty day notice period for the commencement of production and a sixty day notice period at any other time.

132 Gulf Cheddarville, supra note 95 at 4:

The Board believes that the onus for dispensation [sic] of production lies with the operator. Consequently each tract owner has the option to take in kind his share of production or have the operator sell it for him.

Imperial wanted to have Gulf dispose of its share of production "due to market constraints." See for example Order No. P 145, supra note 128 at s. 6(2): see discussion infra note 219. 
price."135 The Board's reasoning has been similarly scant in the one case in which an operator requested that it be allowed to charge a marketing fee. ${ }^{136}$

\section{ELEMENTS OF THE ORDER: TIMING OF THE WELL}

The Act does not provide (in the situation where the well has not been drilled at the time the application is made) that a well should be drilled within a particular period of time. However, the Board's standard form stipulates that the well will be drilled within six months. Some support for that practice is found in s. 74(2) which provides that the Board may hold a hearing to consider varying, amending or terminating an order on a number of grounds including that "a well required by the order to be drilled is not drilled within 6 months of the date of the order." In some circumstances the applicant has requested, and the Board or its Examiners have granted, extended periods for drilling operations, in one case for as long as two years. ${ }^{137}$ In Gulf's Cheddarville application, the Board accorded Gulf twelve months to drill the well on the basis that it was likely a critical sour gas well. ${ }^{138}$

\section{ELEMENTS OF THE ORDER: ALLOCATION OF COSTS OR EQUALIZATION}

Subsection $72(4)(d)$ of the $O G C A$ requires that an order shall provide for the payment of:

- the actual cost of the drilling of the well whether drilled before or after the making of the order and

- the actual costs of the operation and abandonment of the well.

The subsection also requires that the applicant for the order may only recover the above costs, (including any assessed penalty ${ }^{139}$ ) out of production attributable to an owner assessed with a share of the costs. Section 75 defines the term "actual drilling costs" to include "[t]he cost of drilling the well to, and completing it in, the formation named in the order."

These provisions have proven to be contentious. In the following sections this article deals with Board and examiner decisions on a number of problems. These problems include the treatment of equalization costs in the following contexts: where there have been multiple completions; where the current applicant is a successor in interest to the party that drilled the well; where the well was originally drilled to test an oil target and the applicant now proposes to complete it for gas production; where the applicant seeks

\footnotetext{
135 Ibid. at 4.

136 Gulf Leduc Gas, supra note 50 at 5: "The examiners do not consider it necessary that the pooling order ... expressly provide for a marketing fee."

139 See below at Part XI.
} 
to have other tract owners pay for capital costs associated with pipelining or processing; and finally, where the applicant or other tract owners raise issues as to responsibility for abandonment costs.

The leading decision on many of these problems is the Board's Gulf Fenn-Big Valley decision of $1990 .{ }^{140}$ However, subsequent practice of the examiners has been far from consistent.

\section{A. GENERAL APPROACH}

The Board has stated that in fulfilling its obligation to make an order as to the actual cost of drilling the well, it does not need to undertake "a detailed determination of the actual dollar amount owed by one party to the other."141 It is sufficient for the Board to identify the component costs or the broad principles to be followed. The Board will not disallow costs merely because another tract owner asserts that it could have drilled and completed the well more cheaply. ${ }^{142}$

Subsection 75(1) makes it plain that the cost of drilling a well includes the cost of completing the well. This clarification is important as the industry typically differentiates between the two categories of costs. ${ }^{143}$

\section{B. MULTIPLE COMPLETIONS}

As noted above, ${ }^{144}$ s. $75(1)$ serves as an additional definition section for $\mathbf{s s .} 72$ and 73 , and while it expands the scope of the meaning of drilling costs, it also specifies that the eligible costs are the costs of drilling to and completing in "the formation named in the order." This subsection therefore provides some statutory guidance to the Board in dealing with cost equalization for a well that has multiple objectives (e.g. oil and gas zones) or multiple potential completion zones.

In the leading decision on cost allocation or equalization, the Gulf Fenn-Big Valley decision, ${ }^{145}$ Gulf had been unable to negotiate voluntary pooling arrangements with Shaman (another tract owner) for six different spacing units. The primary difficulty

Gulf Fenn-Big Valley, supra note 6.

Ibid. at 7.

lbid. In Gulf Fenn-Big Valley, supra note 6, Shaman alleged that Gulf's drilling and completion costs were approximately 150 percent higher that its own costs would have been (ibid. at 6). The Board commented that in reviewing drilling and completion costs, the Board would have regard to an operator's obligation to follow the Board's regulations and would scrutinize the applicant's drilling practices. In the present case "the differences that appear to exist" between the costs of Shaman and Gulf "are strictly a result of differences in operating practices between the two companies" (ibid. at 7).

See CAPL 1990, supra note 127: the agreement defines drilling costs (at para. 101(k)) as all monies expended with respect to the drilling of a well exclusive of completion costs and equipping costs.

See above, Part III.

Supra note 6. 
seems to have been Shaman's belief that Gulf's drilling costs were excessive. In each case, Gulf had already drilled the wells and incurred the costs.

Of the six wells in question, five were drilled to Basal Belly River Sand and one well (the 7-27 well) was drilled to, and completed in, a deeper horizon. Gulf was confident that it could dually complete the 7-27 well in the Basal Belly River Sand. Gulf had also completed the other five wells in shallower formations including other Belly River Sands and the Edmonton Sand. Some of these shallower zone completions showed potential for commercial production, but Shaman argued that in some cases the shallower zones were non-commercial and therefore it should not be responsible for a share of the costs.

The Board granted Gulf's applications and in the course of doing so provided guidance to the parties on cost allocations for both the 7-27 well (the deeper formation well) and the other shallower dual completion wells. The Board acknowledged that the 7-27 well was drilled for the purpose of evaluating deeper formations. ${ }^{146}$ However, its potential for completion in the Basal Belly River Sand meant that the tract owners within that zone could avoid the cost of drilling a Basal Belly River Sand well. If Gulf were able to charge Shaman for its full share of the avoided costs, Gulf would receive a windfall for a well that it had, after all, drilled for other purposes. ${ }^{147}$ On the other hand, Shaman would receive a windfall if it were not required to contribute to the cost of the well. The Board resolved these competing interests by discounting the avoided drilling costs by one half and apportioning that discounted cost to tract owners on an acreage basis. The Board fixed the avoided drilling cost as the average of Gulf's actual costs for five other Belly River wells, less any extraordinary expenses. ${ }^{148}$ In an addendum to its decision, the Board confirmed that the only costs that were to be discounted were the drilling costs. The parties would share the actual undiscounted completion costs on an acreage basis. ${ }^{149}$

With respect to the other wells, the primary difficulty for the Board was one of determining when other tract owners should be obliged to pay for multiple completions

Ibid. at 7.

Earlier decisions of the Board tended simply to disallow any costs associated with the deeper well. They did not further discount the allowed cost on the basis that the well was also used for other exploratory purposes. In some cases that may simply be as a result of the way in which the issue was posed by the parties. See e.g. Phoenix Resources Company, Special Drilling Spacing Unit, Compulsory Drilling [sic], Morinville Field, Examiners' Report E 82-31 at 9-11 [hereinafter Phoenix Resources] (well drilled as a Leduc well and completed for gas in the lower Mannville); the examiners held that equalization should be limited to the costs of drilling and completion in the Mannville.

Supra note 6 at 7 . The decision was followed on this point by a panel of examiners in Pembina Resources, supra note 85. Pembina drilled the 12-4 well to develop oil production in the Cardium. On an application to pool the gas rights in the Belly River Pool, the examiners ordered that the tract owners should be required to share one half of the average cost of drilling a Belly River Zone well in the area of application. In addition, the examiners ordered that the costs should be void of the costs of segregating the Cardium oil zone from the Belly River Gas zone since these costs would not have been required for a single zone Belly River well (supra note 85 at 5).

Addendum to Decision D 90-9 (supra note 6), (14 December 1990) at 2. 
in shallower zones. In the Board's view, the Act required that completion costs for each zone should be segregated and other tract owners should only be obliged to pay (or in default, incur a penalty) at the time that each zone goes on commercial production. ${ }^{150}$ In a second addendum to its decision, the Board dealt with the contention that this recovery deferral applied not only to completion costs but also to an allocated portion of drilling costs. The Board rejected the argument, ruling that a tract owner became responsible for all drilling costs (void of completion costs for non-producing formations) as soon as the well goes into production and that all drilling costs are chargeable against all production revenue from all producing zones in the wellbore. ${ }^{151}$

Since this landmark decision, the examiners have ignored Fenn-Big Valley at least as often as they have followed it. The decision was followed in an application from Pembina Resources in $1991^{152}$ but in other cases the examiners have proven to be extremely reluctant to discount for equalization purposes the cost of a well that the applicant had drilled to explore other zones. ${ }^{153}$ Two examples will make the point: Imperial Oil's 1996 Willesden Green application ${ }^{154}$ and Gulf's 1995 Leduc Gas application. $^{155}$

In the Imperial Oil decision, Imperial had acquired an interest in a well drilled in 1981 by Texaco. Imperial acquired Texaco's interest through amalgamation in 1989. The well had been drilled as a multiple completion well in the NE quarter and set with 7" casing. The well was completed and abandoned in the deeper Shunda formation and subsequently perforated in both the Cardium and the Glauconitic Sand from which it produced oil and gas until, respectively, May 1984 and January 1996. The facts are a little unusual in that Mutiny acquired the mineral rights in the balance of section 25 effective 1 April 1995, apparently as a result of a mistaken surrender or conveyance of the property. When Imperial realized its mistake some months later in November 1995,

The Board also believes that an implication exists within its pooling legislation that a formation must go on production before the well costs for that formation are required to be paid by tract owners. In this regard the Board believes that the well costs upon the commencement of production should include those drilling and completion costs only to each of the additional producing formations. In the event that another formation goes on commercial production at some future date, then the Board believes that Gulf would be obligated to wait until that time to recover any completion and drilling costs for the other zone from the tract owners in the DSU. In this way, if additional formations go on production that Shaman, or any other tract owner consider non-commercial, they can decide at that future date to pay those completion and drilling costs for that zone immediately, or elect to have their share of costs come out of their share of production from the specific formation (ibid. at 7).

Addendum 2 to Decision D 90-9 (supra note 6), (27 March 1991) at 2. This is consistent with earlier decisions (see Ashlu, supra note 5 at 5; and see also Mission Resources, supra note 33 at 4).

152 Supra note 85.

1s3 See Prairie Pacific Energy Corp. v. Scurry-Rainbow Oil Lid (1994), 52 C.P.R. (3d) 289 (Alta. Q.B.).

1st Imperial Oil Resources Ltd., Compulsory Pooling, Willesden Green Field, Examiners' Report E 96-9, and Order No. P 146 (18 December 1996) [hereinafter Imperial]. 
the parties commenced pooling negotiations but were unable to agree upon the equalization costs for which Mutiny should be responsible.

The examiners made several rulings in the course of their decision. First, in the absence of data on the actual cost of the well, the examiners considered it reasonable to use the book value of the well established at the time of the Imperial Texaco amalgamation as a starting point for the calculations. ${ }^{156}$ Second, the examiners thought that it was appropriate to deduct from this amount all costs associated with drilling and completing the well in the Shunda and Cardium Formations as well as the cost of drilling a larger size hole. ${ }^{157}$ Third, the examiners rejected Mutiny's proposal to make a further deduction to account for the windfall that would otherwise accrue to Imperial (i.e. there would be a windfall if Imperial were able to share the full costs of a well - minus specific deductions - that had been drilled to achieve multiple objectives). The examiners gave no reasons for rejecting the precedent established by the Gulf Fenn-Big Valley decision or the principles underlying the Board's reasoning in that case. ${ }^{158}$ Fourth, the examiners rejected Mutiny's argument that there should be appropriate deductions to account for the fact that the party who originally drilled the well would have obtained credits in the form of drilling incentives and gas royalty holiday. The examiners gave no reason for this conclusion other than that they were "not appropriate or relevant."159 It is apparent that the main difference between this case and Fenn-Big Valley lies in the reluctance of the examiners to discount the cost of drilling the well in addition to making it void of deeper completion and drilling costs.

The examiners took a similar approach in a gas cap pooling application from Gulf in $1995 .{ }^{160}$ Gulf had originally drilled a Leduc formation oil well on the NE quarter in 1985. The well produced only 125 cubic metres of oil before it was shut in. Gulf proposed to recomplete the well as a gas well and sought a compulsory pooling order. Gulf argued that it should be allowed to charge for the costs of drilling the 16-9 well minus the costs of completing the well for oil production but with the addition of the recompletion costs for gas production. The examiners accepted that submission noting that the other parties would receive a windfall if they had only to pay for the cost of completing the well as a gas producer. The examiners did not consider the corollary argument that the parties to the oil well would receive a windfall if they are able to share the full cost (void of oil completion) of a well that was originally drilled as an oil well. As in the previous Imperial Oil Ltd. case, perhaps the examiners were influenced by the fact that the well had never recovered its costs as an oil well.

A different panel of examiners reached a diametrically opposed conclusion on equalization issues in a 1995 application from Penn West. ${ }^{161}$ Penn West assumed

Supra note 154 at 4.

Ibid. at 4.

Ibid.

Ibid. at 4-5.

Gulf Leduc Gas, supra note 50.

Penn West, supra note 114. 
ownership of a producing gas well. It proposed to re-enter the well and complete it for production from an additional zone for which it only had an interest in the east half of the DSU. Norcen held the interests in the west half. For reasons that are not clear on the face of the decision, Penn West agreed to forego recovery of the original drilling costs of the well and requested only equalization for the costs of completing the well in the new zone. The examiners concurred with that result. Given the way the application was framed, it is hard to fault the examiners but the result was to give the Norcen interests a windfall. A fairer result would have required some recognition of the avoided costs that accrued to Norcen from not having to drill a new well to this formation.

\section{CONCURRENT PRODUCTION SCENARIOS}

What is an appropriate methodology for equalizing costs in a concurrent production scenario, bearing in mind that there may be multiple wells within the DSU capable of producing the pooled substances? ? $^{162}$ Once again, the practice is not consistent, but perhaps again due in part to the stance that the various parties have taken.

In the first concurrent production case, the Suncor case, the examiners ${ }^{163}$ decided not to deal with the question of cost allocation for the well on the grounds that neither party considered cost allocation to be an issue. In the result, each party assumed the costs for the well that it had drilled and there was no equalization.

In a more recent decision on an application from Canadian 88 Energy Inc., ${ }^{164}$ and for which there is no Examiners Report, the result was quite different. Whereas in the Suncor case the examiners took the view that there could only be one operator under the terms of a pooling order, ${ }^{165}$ in Canadian 88 the Board designated ${ }^{166}$ Canadian 88 as the operator of the gas well it proposed to drill, but also designated the operator of any oil well producing gas in excess of solution gas as an operator for the purposes of the order. Furthermore, instead of requiring each operator to pay the costs of its own well without equalization, the order makes each well subject to full equalization:

In the Gulf Leduc Gas decision, supra note 50, there was only one well in the DSU. Note also that the concurrent production scenario is not the only scenario in which there might be multiple wells capable of producing the pooled substances in the DSU. It can also occur where there is the possibility for dual completions when different zones are subject to different spacing rules. The examiners have stated that they will not reduce the actual drilling costs for which the applicant seeks equalization on the basis that the intervening tract owner also owned a well in the DSU that could be completed for production in the zone for which the pooling order is sought (Pembina Resources, supra note 85 (argument of Conwest at 4)). The examiners did not provide reasons for their conclusion but they could presumably have justified it on the basis that the applicant is allowed to recover the actual cost of drilling that particular well to the zone in question. See also the discussion of the Ironwood Petroleum decision, supra note 85 (see especially text accompanying note 125 , above).

Suncor, supra note 57.

Supra note 57.

Supra note 57 at 6.

Order No. P 135, supra note 57. The terms of the order are quoted above in the text accompanying note 62. 
If a well subject to this order is placed on production, the owner of each tract shall pay to the designated operator the tract's share of the actual cost of drilling the well to, and completing it in, the formation(s) referred to in clause 1 ... [on an acreage basis]. ${ }^{167}$

The basis for this conclusion is far from clear. Why should a party interested only in the gas production have to pay a full acreage share of the undiscounted cost of a well that was drilled as an oil well?

\section{COSTS NOT INCURRED BY THIS APPLICANT OR BY PARTIES TO THE PRESENT APPLICATION}

Although the Act is silent on this matter, the Board has ruled that where the costs of the well have not been directly incurred by the applicant, or a party to the current application, those costs will be treated as sunk costs for which the operator will not be entitled to recover from the other tract owners. However, if the applicant needs to expend funds to bring a shut-in well back into production, those costs will be eligible for recovery. A case in point is the Board's 1990 Durish decision. ${ }^{168}$

At the time of the application, the section was divided into four separate tracts with one shut-in sour gas well, the 13-21 well, licensed to Seascape. Both Seascape and Durish applied for compulsory orders and each applied to be appointed as operator. Durish argued that it was inappropriate for the Board to allocate a share of the original drilling costs to present tract owners for two reasons. First, the well had produced for four years and the net revenue sufficed to allow the original parties to recover their costs. Second, the pooling legislation was not designed to allow a party to recover a share of the costs for a well acquired in a business venture outside exploration and development for oil and gas. Seascape argued that both original drilling and equipping costs were recoverable. The Board sided with Durish on this and other issues:

The Board believes that a compulsory pooling order requiring payment of the costs of drilling and completing a well is intended to be reimbursement for the actual costs incurred by the recipient. It is effectively a reimbursement by those parties who would benefit by production through the well to those parties who assumed the costs and risks associated with drilling and completing the well.

The Board has determined that none of the parties before it directly incurred the capital costs and risks of drilling and completing the 13-21 well, and therefore should not be reimbursed for costs and risks not assumed. For the same reason the Board believes the application of a penalty against drilling and completions costs would be inappropriate.

The Board recognizes, however, that costs that should be considered drilling costs in accordance with section $\mathbf{7 5}$ of the Act may accrue as a result of work to be done on the well in an attempt to get it back on production. The Board believes that tract owners should be responsible for their share of well costs. Any order, therefore, will provide for the recovery of these well costs, but with the understanding that these will only be those well costs required to allow production to resume through the 13-21 wellbore. 
In addition, any reasonable costs incurred by Seascape for maintenance of the shut-in well should be shared by the tract owners. ${ }^{169}$

In a 1995 examiners' decision, the applicant, PB Resources, applied for a compulsory pooling order and to transfer two well licences for existing wells which had been drilled by a person that was still a tract owner. The examiners decided that the original tract owner, Prescott, should be entitled to some compensation based upon a fair value for the existing wells. The Board fixed this at 50 percent of actual drilling costs. ${ }^{170}$ The examiners did not refer to the Durish decision but Durish may well have been distinguishable on the basis that in PB Resources, Prescott still had an interest in the DSU.

\section{E. TREATMENT OF DOWNSTREAM COSTS}

Section 72(4) of the Act requires that any order must make provision not only for "the actual cost of the drilling of the well" but also for the actual costs of the "operation and abandonment of the well." Unlike drilling and completion costs, the Board will not capitalize downstream costs that the operator may incur to tie in production from the well to a processing plant or pipeline network. ${ }^{171}$ This does not mean that the parties other than the applicant obtain a free-ride through this phase of production and marketing, but it does mean that an applicant can only recover costs as operating costs on the basis of something like the industry approved standard, the Jumping Pound formula. ${ }^{172}$ Thus, in its 1982 Voyager Petroleums decision, the Board noted that the costs related to the construction and operation of a pipeline required for the operation of the well would have to be included in operating costs and "allocated to each tract on a cost of service basis."

Ibid. at 11. Compare this decision with the examiners' decision in Imperial, supra note 154. In that case the Board allowed Imperial to recover the full costs of completing a well in the pooled formation in a situation in which it assumed the assets of the entity that had originally drilled the well. Note that if the examiners refuse to allow the applicant to recover its costs the result will frequently be a windfall to other tract owners.

PB Resources, supra note 38; the examiners noted that Prescott might also receive some benefit from this insofar as it would now be able to spread the costs of abandonment with other tract owners (ibid. at 4). See also Ironwood Petroleum, supra note 85. The 2-18 well had been drilled by a predecessor in interest of Ironwood in 1994. The examiners allowed Ironwood to equalize costs for completing the 2-18 well but agreed with Ironwood that it would be "inappropriate for the pooling order to specify the sharing of the costs of drilling the 2-18 well, because none of the existing tract owners incurred these costs" (ibid. at 9).

Durish, supra note 118 at 11 . In Pembina Resources, supra note 85 at 5 , the examiners rejected Pembina's application to equalize and charge a 150 percent penalty on capital costs associated with pipeline and transmission facilities.

For background to the Jumping Pound (JP) Formula see "In re Shell Oil of Canada Ltd." in Bennett Jones Verchere, Barristers and Solicitors \& N. Bankes, eds., Canadian Oil and Gas, $2 \mathrm{~d}$ ed., vol. 1, (Toronto: Butterworths, 1993) 392 (Digest 70); and see also Digests 71 and 72 . The Board endorsed the JP-90/95 "Joint Industry Task Force Report on Processing Fees JP-95" in Rider Resources Inc., Common Processor, Pembina Field, Decision D 97-2. 
In its 1995 Leduc Gas application, Gulf asked the examiners to grant it a 2 percent marketing fee for any gas of the tract owners that it ended up marketing. ${ }^{174}$ The intervenor stated that it had no objection to the provision of a marketing fee in the order ${ }^{175}$ but the examiners stated that they did not consider it necessary to provide for a marketing fee in the terms of the order. ${ }^{176}$

\section{F. COSTS OF, AND RESPONSIBILITY FOR, ABANDONMENT}

As noted in the last section, an order must inter alia make provision for the costs of abandoning the well. The Act provides two additional pieces of guidance to the Board on this subject. First, s. 72(4)(b) indicates that it is the designated operator that is to be "responsible for the drilling, operation or abandonment of the well." The effect of this paragraph is to place full responsibility on the operator for abandonment unless there is some other mechanism for shifting responsibility. The paragraph also distinguishes between drilling costs and abandonment costs. ${ }^{177}$ Second, s. 72(4)(d) provides that the payment of actual costs chargeable to tract owners "shall be recoverable only out of that owner's share of production." This paragraph suggests that any attempt by the operator to share responsibility for abandonment with other tract owners will be less than successful unless the operator is authorized to set aside funds from production to pay for abandonment before the well goes dry. What is the Board's practice in dealing with responsibility for abandonment in light of these statutory provisions?

The first treatment of the issue appears to be the examiners' decision on Voyager's 1982 application for the Norris Field. Voyager indicated that one of the reasons that it had been unable to reach an agreement with Lazarenko, the other tract owner, was that Voyager was not prepared to include a clause in the voluntary agreement limiting his personal liability with respect to the well's costs because "there would be future costs attributable to the well after production has ceased." 178 The examiners dealt with this in their decision as follows:

The examiners believe that the liability of Mr. Lazarenko is strictly defined and limited under the Act and the normal terms of a compulsory pooling order to the costs which can be recovered from the sale of production from the well. ${ }^{179}$

However, in recent years, tract owners have clearly become increasingly concerned about the issue, although the examiners have not provided much useful guidance. In

Gulf Leduc Gas, supra note 50 at 3.

Ibid. at 4.

Ibid. at 5.

Compare practice in the industry under the terms of an operating agreement. In the CAPL Operating Agreement, supra note 127, "drilling costs" are defined to include abandonment costs in the event that the well is not completed. For discussion see Renaissance Resources Lid. $v$. Metalore Resources Lid., [1984] 4 W.W.R. 430, affd [1985] 4 W.W.R. 673 (Alta. C.A.), and Novalia, supra note 129.

Ibid. at 5. 
Imperial Oil's 1996 Willesden Green application discussed above, ${ }^{180}$ Mutiny, the other tract owner, asked that the pooling order specifically state that downhole abandonment for the Cardium and Glauconite be the responsibility of the mineral rights holders of the respective zone, and that uphole remedial work and surface reclamation costs should be shared by the Cardium and Glauconite owners. The examiners took the view that since Imperial and Mutiny apparently had similar views on this matter, it was not necessary to deal with it in the order. ${ }^{181}$

Liability for abandonment was also addressed in the PB Resources decision of the examiners. In that case, PB was applying for the transfer of existing well licences as well as a compulsory pooling order. The examiners noted that one result of the orders would be to allow the existing licensee to transfer 90 percent of the abandonment costs to other parties within the DSU. ${ }^{182}$

Finally, liability for abandonment was also addressed in the Board's 1995 decision on Gulf Canada's Leduc Gas application.

\begin{abstract}
Abandonment costs should be handled according to normal practice under a pooling order. Such practice would have the abandonment costs paid solely by Gulf if the well recompletion were unsuccessful; however, if the well produces, subsequent abandonment costs would be shared by all tract owners. ${ }^{183}$
\end{abstract}

The point was an important one in the particular case because the intervenors were effectively arguing that a greater proportion of abandonment costs should be borne by those parties that had an interest in the well when it was originally drilled as an oil well on quarter section spacing. The examiners' response did not deal with this matter, ${ }^{184}$ or point out, as had the Board in the Voyager case above that such costs, even if shared, would only be recoverable out of production.

In light of this last point, does the form of the Board order offer the operator any comfort? The answer must be no. The standard form pooling order contains only two provisions dealing with the cost of abandonment. In the first provision in the standard form the Board merely fulfills its statutory responsibility under s. 72(4)(b). Thus in Order No. P 145 for example, the order simply states that:

3. Talisman Energy Inc. (hereinafter called the "operator") shall be the Operator of the said well and shall be responsible for the well and for all completing, producing and abandonment operations at the well.

The next clause provides that:

180 Imperial Oil, supra note 154.

181 Ibid. at 6.

182 Supra note 38 at 4.

183 Gulf Leduc Gas, supra note 50 at 5.

18 In effect this was another equalization issue that was decided in favour of Gulf; see discussion above, text accompanying notes $161 \mathrm{ff}$. 
4. The cost of drilling, operating and abandoning the well shall be paid by the Operator, subject to the terms and conditions hereinafter contained. ${ }^{185}$

Here is the catch. While the order makes extensive provisions in its subsequent paragraphs for sharing drilling and operating costs, it makes no subsequent provision for sharing abandonment costs. In conclusion, the operator under a pooling agreement would appear to be in an unenviable position. The terms of the order make the operator responsible for abandonment costs and there is nothing in Part XII of the Act or the balance of the order to relieve it of this responsibility.

Do the 1994 amendments to the $A c t^{186}$ to deal with the problem of orphan wells ${ }^{187}$ change this conclusion? It is difficult to reach a final conclusion on this point, which is properly the subject of a separate note, for the legislation is far from explicit. Section $20.3(1)$ provides that well abandonment costs, a defined term, ${ }^{188}$ shall be paid by the working interest ${ }^{189}$ participants in accordance with their proportionate shares in the well. Subsection (4) goes on to say that these costs, together with any penalty, constitute a debt payable to the party that carried out the abandonment. What has not been addressed by the drafter is the relationship between s. 20.3 and s. 72(4) and the terms of a compulsory order. A preliminary view is that since the language of the orders provides no basis for charging tract owners with abandonment costs, and given that s. 72(4)(d) is a more specific statutory provision than is s. 20.3, then, even if a tract owner has a liability for abandonment by virtue of s. 20.3, it is still a liability that can be satisfied only out of actual production. This conclusion is reinforced by $\mathbf{s}$. 80 of the Act which was amended in 1994 as part of this package of amendments.

Prior to the 1994 amendment, s. 80 established two things. First, it provided that a tract owner's liability for operating expenses is several, and not joint, and second, it provided that a tract owner could not be obligated or liable for any more than its liability pursuant to the plan of operation. The amendment in 1994 added the words "subject to s. 20.3(3)" at the commencement of the section. Now s. 20.3(3) is the subsection that allows the Board to assess a penalty in the event a working interest participant fails to pay its share of abandonment costs within the prescribed time. It is therefore clear that the subsection was intended to amend the second part of $\mathrm{s} .80$ which served as a cap on liability. Since the section (i.e. s. 80) is concerned with

18s Order No. P 145, supra note 128 [emphasis added].

186 S.A. 1994, c. 26.

187 See also ERCB, Interim Directive (ID) 93-2, "Requirements for the Issuance of a Well Licence or Approval of Well Licence Transfers" (2 July 1993).

$188 \quad O G C A$, supra note 2 , s. 1(1)y.1.

189 This is another defined term (ibid., s. 1(1)y.2) meaning a person "who owns or controls all or part of a beneficial or legal undivided interest in a well under agreements that pertain to the ownership of that well" [emphasis added]. There are at least two problems with this definition in the context of pooling orders and indeed pooling agreements. First, do the italicized words embrace a tract owner that has an interest under the terms of a compulsory pooling order? Second, if a pooling operates as an administrative pooling rather than a cross conveyance pooling (whether by order or agreement) is it accurate to describe a tract owner that does not have the well on its lands as the owner of an undivided interest in the well? 
operating expenses, ${ }^{190}$ it may be questioned how successful it has been in changing that objective. But even if the amendment has been successful in extending the term "operating expenses" to include abandonment expenses, it does not follow that it has also amended s. 72(4)(d) which makes it clear that any liability of a tract owner can be satisfied only out of actual production.

All of this leaves the operator in an exposed position. That may have been the intention when these provisions were first added to the $O G C A$, but it is doubtful whether that is appropriate now. It is hard to see why a tract owner's liability for abandonment costs should be confined to its share of production in all cases. A possible solution might be for the Board to change the terms of its standard order to allow the operator to retain a portion of the tract owner's share of the proceeds of production in trust to pay for estimated abandonment costs. This could still be structured in a way that would offer some protection to the tract owner that did not wish to participate in the well because it doubted the economics of the operation, but it would also offer a measure of protection to the operator who might face the abandonment liability alone even if the well had been a successful producer.

\section{ELEMENTS OF THE ORDER: THE PENALTY PROVISION}

\section{Section 72(5) of the Act provides that:}

The Board may in its order specify that, in the event production of oil or gas is obtained and the owner of a tract fails to pay his share of the actual cost of drilling the well by the time specified in the order, then the amount payable by the owner shall include, in addition to his tract's share of the actual cost of drilling, a penalty payable to the operator in an amount equal to not more than 2 times his tract's share of the actual cost of drilling.

The current language of the Act reflects an amendment made in $1990 .{ }^{191}$ Prior to 1990 , the maximum penalty was limited to one half of the tract's share of the actual cost of drilling. ${ }^{192}$

\section{A. HISTORIC PRACTICE}

The Board's early practice in relation to the penalty seems to have reflected some confusion as to two separate issues: (1) the penalty payable, and (2) the possibility that the operator was entitled to interest upon the outstanding balance payable by a tract

There is yet another difficulty here. The marginal note for 5.80 reads "operating expenses." This phrase is repeated in the first part of the clause dealing with several and joint liability; do these expenses form the subject matter of the balance of the section? It appears so, see the reference to such an owner. Furthermore, if the drafter wished to avoid the overall cap on liability by the reference to s. 20.3(3) why did s/he not simply qualify the second part of the section? Apart from the 1994 amendment, this section has not been amended since first enacted in 1957 (see S.A. 1957, c. 63, s. 86). 
owner. Thus, commencing with Order No. P 4, issued in 1958, until approximately 1982 , the penalty provision took the following form: ${ }^{193}$

A tract's share of the cost of drilling the well shall bear interest at the rate of 6 per cent per annum from the time the well is placed on production until the share is paid; provided, however, that the aggregate amount of interest payable shall not exceed 50 per cent of the tract's share of the actual cost of drilling the well.

This form of stipulation effectively equated the payment of interest with penalty. The two concepts were not severed in Board orders until its 1982 decision on an application from Ashlu Exploration which made it clear that an operator was entitled to both a penalty and interest:

The examiners further believe [i.e. in addition to a penalty] that interest should be applied to all monies, including the penalty, not paid within the time specified. Since a non-participating party has the right to pay its share of costs within the time set out in the pooling order, and incur neither a penalty nor interest charges, the examiners believe that if the non-participant fails to pay its share of costs it should be charged interest on the outstanding amount until its share of the costs and penalty have been paid. ${ }^{194}$

The examiners' decision was affirmed by the Board and ultimately the terms of the order. ${ }^{195}$ That, however, appears to have been something of an aberration, as subsequent orders of the Board have provided for the maximum penalty stipulated by the Act, but they have not made an additional provision for the payment of interest. The issue was raised most recently in Gulf Canada's Cheddarville application in 1986. Gulf sought the maximum penalty plus interest at prime plus 1 percent payable on the unpaid portion of a tract's share of drilling and completion costs. The Board denied that request on the basis that the penalty plus interest exceeded that permitted by the $A c t .{ }^{196} \mathrm{In}$ reaching that conclusion the Board relied on what is now S. 72(5) of the Act. ${ }^{197}$

Order No. P 4 (6 November 1958), Jefferson Lake Petrochemicals Ltd., Compulsory Pooling, Crossfield Formation, s. 7(4). In some later cases the applicable interest rate rose to 17.5 percent (Orders No. P 48 (8 April 1980), Trans-Canada Resources Ltd., Compulsory Pooling, Wainwright Field; and P 49 (8 April 1982), Trans-Canada Resources Ltd., Compulsory Pooling, Wainwright Field).

\section{Supra note 5 at 4.}

Order No. P 52 (23 June 1982), Ashlu Exploration Ltd., Compulsory Pooling, Elnora Field, s. 7(4):

The unpaid portion of the tract's share of the actual cost of drilling the well plus the penalty shall bear interest at the prime rate plus one per cent per annum as calculated on and accruing from the time provided for the payment of the share in subclause (2) until the share is paid [emphasis added].

Supra note 95 at 4.

Ibid. But is there not a distinction between interest and a penalty? This distinction is recognized in $\mathrm{s} .78$ of the $A c t$ which provides that where there is a title dispute and the operator pays the proceeds of production to the Provincial Treasurer the owner is not entitled to interest or a penalty on the sums held by the Treasurer. Note that $\mathbf{s .} 80$ should not present an obstacle to an operator recovering interest and a penalty, since, while s. 80 imposes a cap on liability it is concerned with liability for operating costs and not drilling costs. See discussion supra note 190. The 1981 CAPL Operating Agreement provided that interest was payable on those equipping costs that had not been paid. Interest was not payable on any other costs including drilling costs and completion costs 
Consistent with that statement, the current standard form allows the operator to charge a penalty, but does not allow it to claim interest on outstanding sums. ${ }^{198}$ The order has been in this form since 1982 .

\section{B. CURRENT PENALTY PRACTICE}

The language of the section gives rise to four questions. First, when will the Board exercise what is apparently a discretionary power ("may") to award a penalty and, if it awards a penalty, will it ever be less than the maximum prescribed by the $A c t$ ? Second, what time will the Board typically specify in the order as the time by which payment shall be made to avoid incurring a penalty? Third, what is the penalty a multiple of? Fourth, what is the appropriate treatment of production during the penalty period?

\section{Exercise of the Board's Discretion}

\section{a. The Missing and Untraceable Tract Owner}

There is one situation in which the Board has no discretion as to the availability of a penalty. This follows from s. 72(6) of the Act which provides that subsection (5) "does not apply to the owner of a tract who is missing and untraceable" (i.e. no penalty is payable). ${ }^{199}$ An owner will be treated as missing and untraceable for the purposes of this section if the Board is satisfied that the applicant has made reasonable and diligent efforts to find the owner. ${ }^{200}$ If the applicant wants to charge a penalty, it is in its own interests to track down the tract owners.

The Board will also treat the owner as being untraceable or missing if timeconsuming and lengthy legal proceedings would be required to determine an owner, as in the case of railway lands ${ }^{201}$ or lands for which the Land Titles Office acknowledges errors in the chain of title..$^{202}$

In one case there was an issue as to whether or not an owner really was untraceable for the purposes of s. 72(6). ${ }^{203}$ The case involved an application to pool certain lands

(para. 1007). The interest provision has been dropped from the penalty clause in the 1990 CAPL, supra note 127, and replaced by a 200 percent penalty on equipping costs (para. 1007) for reasons of administrative efficiency (J.A. McLean, "The 1990 CAPL Operating Procedure: An Overview of the Revisions" (1991) 30 Alta. L. Rev. 133 at 166).

See e.g. Order No. P 145, supra note 128, s. 8(3).

APL Oil and Gas Ltd., Compulsory Pooling, Medicine River Area, Examiners' Report E 85-18 at 5.

See e.g. Dekalb Petroleum Corporation, Compulsory Pooling, Nevis Field, Examiners' Report E 86-26 at 3 [hereinafter Dekalb Petroleum]; Canadian Occidental Petroleum Ltd., Compulsory Pooling, Okotoks Field, Examiners' Report E 84-24 at 172. Occidental Petroleum Ltd., Compulsory Pooling, Okotoks Field, Examiners' Report E 87-12; Dekalb Petroleum, ibid. 
with a unit operation. The applicant, Gulf Canada, had an interest in both tracts as a Crown lessee of LSDs 7, 8 and 1, and in LSD 2 as a party to a unitization agreement. The registered Crown lessee of LSD 2 was Chevron, the unit operator. Chevron was unwilling to enter into a voluntary pooling agreement because one of the working interest owners within the unitized tract was missing and untraceable and it therefore could not obtain the unanimous consent of the working interest owners within the unit. Gulf initially commenced the application seeking, as a term of the order, an allocation of the missing owner's share of production under s. 77 of the Act. If that application had continued the Board would have had no choice in the matter and would not have been able to order the payment of a penalty. Gulf subsequently changed its mind and argued that Chevron as the unit operator should be treated as the owner, and all attributable production paid to it, leaving it to Chevron to account to the missing owner. The examiners accepted that as a reasonable way of proceeding and awarded the maximum penalty then available under the $A c t .{ }^{204}$

\section{b. Executor Unwilling to Act}

On occasions the applicant will be able to identify the current tract owner but the title may be unclear, or an executor may be unwilling to act. In the case of an executor that is unwilling to act, it may be possible to assess a penalty (the tract owner is not missing or untraceable). In some such cases the applicant will not seek the imposition of a penalty in this situation and, in the absence of an application, the Board considers it inappropriate to grant a penalty. ${ }^{205}$

\section{c. Unclear Title}

There are two possible ways for the Board and the parties to deal with the situation of unclear title. One possibility is that the title may be so unclear that one can effectively conclude, as above, that the tract owner is missing or untraceable. The other possibility is that there may simply be a dispute between the registered owner and another party. In that event, the Board appears to be of the view that s. 78 of the Act has some bearing on the matter.

Section 78 provides that where an order has been made by the Board and then a dispute arises, the operator is entitled to sell the production allocated to the disputed tract and pay the monies remaining after a deduction of costs and expenses to the Provincial Treasurer in trust. When this occurs, s. 78(2)(a) provides that the owner is not thereby entitled to any interest, or a penalty from the Provincial Treasurer. In effect, this section provides a self-help remedy to the operator confronted with conflicting claims and the solution offered is similar to an interpleader action. It leaves the onus of commencing the action on the disputing parties that wish to lay claim to the monies held in trust. In the present context it is important to note that the existence of a dispute is not reason for denying a penalty in favour of the operator. The reference to a penalty 
in s. 78(2) does not prevent the operator from collecting a penalty, it merely prevents the owner from collecting a penalty from the Treasurer, and indeed from collecting interest. $^{206}$

\section{d. Other Cases}

In those other situations in which the Board has discretion to award a penalty, it is the Board's invariable practice to award the maximum penalty permitted by the legislation. In some cases the applicant will adduce various reasons for seeking a penalty, such as drainage losses resulting from the delay in being able to put the well on production, but the Board does not seem to require exceptional evidence of this nature. Instead, the Board seems to be of the view, correctly, that a party that takes the up-front risk of drilling should be entitled to the maximum penalty of 200 percent. The Board stated it this way in its Ashlu Exploration decision in 1982:207

The examiners believe that in the case where an operator has demonstrated that he has made reasonable attempts but has been unsuccessful in reaching agreement, and is willing to take the risks in drilling a well and proving up reserves, the application of a penalty as permitted by the Oil and Gas Conservation Act is warranted.

In Gulf's 1995 Leduc Gas application, the intervenor, FCPI, put forward several reasons why it was inappropriate that it pay the maximum penalty of 200 percent. The examiners rejected all of the arguments ruling flatly that the maximum penalty was consistent with Board practice "in this type of case." ${ }^{208}$ The case was unusual because it involved the recompletion of a well that had originally been drilled as an oil well in 1985 (at which time the $A c t$ prescribed a maximum penalty of 50 percent of drilling and completion costs ${ }^{209}$ ). The intervenor argued that while it should clearly have to pay for its share of the gas recompletion costs, as well as any appropriate penalty

It is not clear that the Board has the same view of the scope of $s$. 78. In the Durish decision, supra note 118, there was an ongoing dispute between Durish and another tract owner as to mineral rights in the SW 1/4 (see Durish v. White Resource Management Lid., Royal Bank of Canada and WRM Resources Ltd., [1995] 1 S.C.R. 633). Durish asked the Board for "a pooling order pursuant to $\mathrm{s.} 78^{\prime \prime}$ (ibid. at 5). Seascape objected on the basis that a s. 78 order was inappropriate since Seascape was currently the lessee and Durish was simply a top lessee. Therefore, Seascape argued that the operator of the pooled unit should continue to pay Seascape its share of production until a court ordered otherwise. The Board concluded that it was "satisfied from the evidence that there is a dispute as to lease ownership" and therefore that a "pooling order pursuant to section 78 of the Act is appropriate" (ibid. at 7). Both parties and the Board misconstrued s. 78. There is no such thing as a s. 78 order. Section $\mathbf{7 8}$ does not accord any jurisdiction to the Board. It simply allows an operator a solution in the event of conflicting claims. In short, it is not up to the Board to rule whether there is a dispute, the operator must make that decision. Presumably, as long as the operator makes that decision in good faith and on the basis of some evidence that is the end of the matter. For an Examiners' Report that accepted the concept of a jurisdiction to make a "s.78 order" see Chancellor Energy Resources, supra note 51. An Examiners' Report that accords more with the analysis above is PB Resources, supra note 38 at 3, in which the Board simply noted the existence of $\mathrm{s} .78$. 
attached to that venture, it was inappropriate to require it to contribute to the undiscounted cost of drilling the original oil well, and have to pay full penalty on a risk venture that was not its risk. The intervenor blended together its arguments on two different issues, penalty and equalization, in the hope of obtaining some relief. ${ }^{210}$

The examiners rejected all the arguments in a decision that seems unduly harsh on the intervenor and inconsistent with the legislative scheme. Gulf had originally drilled the well at its sole cost, risk and expense to evaluate the oil potential of its quarter section. To require that the intervenor pay its full share of the original drilling costs (minus oil zone completion costs) and be placed in a potential penalty position for a risk that had already been assumed by Gulf for its own account is penal. The Board's treatment of the equalization of drilling and completion costs in this case is dealt with above, ${ }^{211}$ but a fairer treatment of the penalty would have been to allow Gulf to charge penalty on the incremental costs of the new operation (i.e. the gas recompletion attempt), for that was the only new risk that the applicant was incurring.

A similar result to that contended for here was arrived at in another examiners decision in the same year. ${ }^{212}$ In that case, Penn West assumed the ownership of a gas well (completed in LSD 6) producing from the Paddy Member. Penn West proposed to re-enter the well and dually complete it to allow production from the Cadotte member as well as the Paddy member. Penn West held the rights to the east half of the section in the Cadotte zone while Norcen held the rights to the west half. As discussed above, ${ }^{213}$ the examiners accepted that the only costs that should be subject to equalization and penalty were the incremental costs of the re-entry for dual completion. The examiners, however, rejected Norcen's contention that this should be subject to only a 50 percent penalty and concluded that the full 200 percent penalty was appropriate. ${ }^{214}$

\section{The Time by Which a Tract Owner Must Tender Payment to Avoid Penalty}

The language of the subsection focuses attention on tendering payment "by the date specified in the order" but it is clear that this phrase must be read subject to the previous part of s. 72(4)(d) which reads "in the event production ... is obtained." This makes it clear that there is no obligation to tender in order to avoid the penalty until there is actual production. It is not enough that the well is capable of production, production must have been obtained. Thus, not only does the tract owner have the right to require the applicant to bear all the risk of the operation, the tract owner can also defer making a decision on whether or not to go penalty until the well has actually established itself as capable of production.

See the discussion on equalization above, text accompanying notes $147 \mathrm{ff}$.

Ibid.

Penn West, supra note 114.

See above, text accompanying notes $161 \mathrm{ff}$.

Supra note 114 at 5. 
Recent decisions of the Board stipulate that the tract owner, in order to avoid penalty, must tender its share of the drilling and completion costs within thirty days of the last of three events: (1) the Board issues a pooling order; (2) the operator provides a written statement of the tract owner's share of the cost of drilling and completion, and (3) the operator places the well on production. ${ }^{215}$ In one case where there was an ongoing dispute as to the precise interpretation of a Board order, the Board ruled that the tract owner should be able to avoid penalty if it paid its share of the costs within seven days of the Board's clarification. ${ }^{216}$ Where there are multiple completions and not all zones are placed on production at the outset, a tract owner need not pay the completion costs for those zones not placed on production and will not incur a penalty for failing to do so, until they are placed on production. ${ }^{217}$

\section{Of What is the Penalty a Multiple?}

The Act currently provides that the penalty cannot be more than 2 times the tract's share of actual drilling costs. Section 75 defines "the actual cost of drilling" to include the cost of completing the well. In a 1982 application, Voyager had argued that it should be entitled to a penalty on its tie-in costs. The Board rejected that proposition noting that the legislation only allowed it to assess a penalty on drilling costs. The cost of an associated pipeline, even if essential to the operation of the well, could not be made the subject of a penalty. ${ }^{218}$

\section{TREATMENT OF PRODUCTION DURING THE PENALTY PERIOD}

The Act is silent on the question of whether or not the operator is entitled to retain all production from the pooled unit until it has recovered drilling and completion costs, ongoing operating costs, and any applicable penalty, or whether it must provide some minimum amount of production to the tract owners immediately upon commencement of production. However, the Board does deal with these issues in its form of approval.

The form of approval gives the operator the right and the duty to sell the tract owner's share of production whether or not the owner has elected to take in kind, and at a price "not less than the current price in the Field."219 The operator must then

See for example Pembina Resources, supra note 85. In some cases a shorter period is specified, e.g. fifteen days in Order No. P 119 ((7 December 1994), Kaiser Energy Ltd., Compulsory Pooling, Fir Field) and in one case the penalty was triggered if the tract owner's share was not paid within thirty days of the delivery of the statement and "the completion and release of the on-site absolute open flow tests of the subject well" (Order No. P 117 (30 March 1994), Lorrac Energy Ltd., Compulsory Pooling, Pembina Field). Is this production or merely evidence of capability to produce?

Gulf Fenn-Big Valley, supra note 6, Addendum 2 at 3.

Ibid. at 2.

Voyager Petroleums, supra note 173; Pembina Resources, supra note 85 at 5.

Order No. P 145, supra note 128, s. 8(3)(b). The "current price in the Field" is presumably the Field in which the pool is located but that hardly offers much guidance when gas prices vary so much depending upon the duration of contract, etc. In Erehwon Exploration Lid v. Northstar Energy Corp. (1993), (1994) 15 Alta. L.R. (3d) 200, Hunt J. noted the difficulties of interpreting the term "field price prevailing in the area" in the gas context in the particular case of cl. 602 of 
remit 20 percent of the proceeds of the sale to the tract owner. Of the 80 percent remaining, the operator shall apply the proceeds of sale (1) to pay the tract's share of operating costs; (2) the actual costs of drilling, and completing the well, including a 200 percent penalty if applicable; and, (3) account to the owner for the balance of the proceeds of sale and in that order. ${ }^{220}$ Thus the 20 percent of proceeds is taken off the top and the operator is not entitled in any month to more than 80 percent of production to cover operating and drilling expenses.

The justification that is usually offered for this arrangement is that it allows each tract owner to satisfy its royalty obligations. Indeed, in some cases, such as Gulf's Fenn-Big Valley applications, the Board, "in the absence of an objection from Gulf," granted a request from the intervening tract owner for an immediate payment of greater than 20 percent in order to meet royalty obligations in excess of the 20 percent. ${ }^{221}$ The Board's willingness to grant the order in the circumstances begs the question: what would have happened if Gulf had objected, or if any operator were to object to an immediate 20 percent payout? The Act provides no explicit authorization for these provisions of Board orders and while the Act provides that a tract owner's share of expenses can only be recovered out of production, the general tenor of the section seems to assume that, subject only to that proviso, the operator is entitled to recover its expenses from the entirety of production. At the very least, the 20 percent figure is entirely arbitrary and, while convenient, it is hard to justify in the event that a tract owner's royalty liability is less than 20 percent.

\section{ELEMENTS OF THE ORDER: EFFECTIVE DATE OF AN ORDER}

In several cases, applicants have requested that the Board make its order retroactive to the date of application. The Board and its examiners have consistently held that they have no jurisdiction to do so, ${ }^{222}$ and have stated that "the date of any order would be the date of issuance, which would follow an approval of the Lieutenant Governor in Council, if such an approval is obtained." ${ }^{223}$ In Ulster, ${ }^{224}$ the vertical pooling case, both parties to the litigation accepted that the Board could not make a retroactive allocation of oil to the parties either through a zone designation order under s. 21 of the $O G C A$ or pursuant to a compulsory pooling order. Given that agreement, Fraser J. was

the 1981 CAPL (at 239 (para. 107)). She went on to note (at 246 (para. 132)) that "While it may be true that "field price" equates more easily to oil than to gas, the simple fact is that cl. 602 applies to both and, according to other experts, in a gas context field price should be taken to mean spot price. I accept this view." See also J.J. Park, "Marketing Production from Joint Property: The Past, the Present and the Future" (1990) 28 Alta. L. Rev. 34.

Order No. P 145, ibid., s. 9.

Gulf Fenn-Big Valley, supra note 6 at 8 and Orders No. P 99 - P 104 (17 January 1991), Gulf Canada Resources, Compulsory Pooling, Fenn-Big Valley Field; and Order No. P 129 (14 September 1995), ibid. Note that in some cases an overriding royalty may not be payable during the penalty period if the payor does not receive production: Mesa, supra note 81 at $196 \mathrm{ff}$. Universal, supra note 46. Amoco, supra note 84 at 11. Supra note 78. 
prepared to accept "for the purposes of this application" that "the ERCB does not have the legislative authority to make a retroactive allocation."225

Notwithstanding these rulings, the Board or its examiners have, on occasion, made creative use of equalization conditions to achieve the result of a retroactive order without actually making the order retroactive. The Board's capacity to effect this result will be appreciated once it is understood that, in the usual case, ${ }^{226}$ the need for a retroactive order will arise from the fact that a well will have been producing on the spacing unit without the agreement of all tract owners, and therefore in breach of s. 13 of the OGCA. In such a case, as noted above, ${ }^{227}$ it is hard to find a principled basis for reaching the desirable result and to require the operator to share production with other tract owners. However, the operator's case for equalization of its drilling costs will be diminished to the extent that it has recovered the cost of drilling the well from actual production.

The Board took this view of the facts in an unusual application brought by Amoco. ${ }^{228}$ The facts were as follows. Section 8 was divided into two tracts. The north half was held by Amoco; the south by Norcen/Hydrogas. The 6-8 well was drilled on the lands in 1972 and was, at the time of the pooling application, licensed to Hydrogas. The parties had discussed a possible pooling agreement between 1974 and 1982. In 1975 , the 6-8 well was placed on production as an emergency measure to ensure an adequate supply of gas to the town of Manning. Some years later, Amoco commenced this application for a pooling order!

The examiners granted the order and accepted Amoco's argument that the actual costs of drilling and operating the well had already been recovered out of production. Consequently, no funds were owing by Amoco and there was no need for a penalty. The examiners reasoned as follows:

Regarding Norcen's concern that the Board might issue an order which would attempt to retroactively deal with revenues obtained from production prior to the effective date of an order issued, the examiners point out that they believe it is not within the jurisdiction of the Board to make a declaration as to who is entitled to revenues from production and in what proportions. Section 72(4)(c) of the Act allows only for the allocation of the share of production to each tract and that section does not give the Board jurisdiction to deal with the allocation of revenues from production.

The examiners believe that the question of whether Amoco is entitled to share in the revenues obtained from production is relevant only to infer whether or not the costs of drilling the well have been paid out, and therefore, whether a penalty, as allowed by section $72(5)$, is necessary.

Ibid. at 144 (para. 38). In the course of reaching this conclusion Fraser J. also reviewed one of the leading cases (Nova v. Amoco Canada Petroleum Co. Ltd (1981), 128 D.L.R. (3d) 1 (S.C.C.)). Situations can also be imagined in which a party might wish to have the order made retroactive in order to save a freehold lease. See, for example, the facts of Chancellor Energy, supra note 51. Supra note 39. 
The examiners believe that 50 per cent of production to date should be attributed to the north half of section 8 , and accordingly, the examiners do not believe there is a need to prescribe a penalty provision for the payment of drilling costs, pursuant to section $72(5)$, since the examiners believe the evidence enables them to conclude that the costs of drilling the 6-8 well have been paid out from production obtained from the 6-8 well. ${ }^{229}$

In effect, the examiners applied an unjust enrichment principle to achieve an equitable result. ${ }^{230}$ The examiners reached a similar conclusion in a 1982 decision involving Voyager. The well in that case was "inadvertently" placed on production in April, prior to a Board hearing commencing in August. By the time of the hearing, or by the time the error was discovered, Voyager conceded that the well had produced roughly enough gas to cover its completing and equipping costs. ${ }^{231}$ In rendering their decision on penalty the examiners seemed to assume that a set-off was possible and that therefore little if any penalty would be payable..$^{232}$

Although the conclusions in these cases seem attractive, a panel of examiners refused to follow their imaginative lead in a 1996 decision involving Imperial Oil's Willesden Green application. ${ }^{233}$ The facts of the case are discussed above. ${ }^{234}$ Both tract owners within the unit, including Imperial, the operator of the well, agreed that the pooling should be effective as of the date that Mutiny acquired an interest in the spacing unit in April 1995. ${ }^{235}$ The timing is significant because the well continued to produce from April 1995 to January 1996 when the well was shut in. On those facts Mutiny argued that any apportionment of actual drilling and completion costs should be net of production revenues owed by Imperial to Mutiny for production until the well was shut in. The examiners rejected that approach apparently relying upon the fact that $\mathbf{s .} 72$ of the $A c t$ did not allow for retroactive application. ${ }^{236}$

$229 \quad$ lbid. at 14.

230 For a loose analogy see Weyburn Security Co. Lid. v. Sohio Petroleum Co. (1969), 69 W.W.R. 680 (Sask. C.A.), affd (1970), 74 W.W.R. 626 (S.C.C.).

231 Voyager Petroleums, supra note 173 at 3.

$232 \quad$ Ibid. at 5.

233 Supra note 154.

234 See above, text accompanying note 154.

23s Supra note 154 at 2.

236

Ibid. at 5 . The issue was not raised in the analogous case of Pembina Resources, supra note 85. In that case the applicant admitted that it had already produced gas from the zone for which it was requesting pooling because it had failed to properly segregate Belly River gas production from Cardium oil. The applicant agreed that the gas production should be allocated back to the Belly River tract owners (ibid. at 3). 


\section{THE EFFECT OF AN ORDER}

The effect of a pooling order is described in ss. 72(7) and 79 of the $O G C A{ }^{237}$ There seems to be significant overlap between the two provisions, perhaps because $s$. 79 is in the segment of Part XII which falls under the heading "General," and which is therefore intended to apply to both pooling orders and compulsory unitization should those sections of the Act ever be proclaimed. ${ }^{238}$

\section{Subsection (7) states that:}

(7) When an order is made under subsection (3),

(a) the drilling for or the production of oil or gas from the designated formation in the drilling spacing unit and all operations incidental to the drilling or production pursuant to the order shall for all purposes, be deemed to be carried on or conducted by the several owners respectively on their separately owned tracts in the drilling spacing unit, and

(b) that portion of the production allocated to each tract, and only that portion, shall be deemed to have been produced from the tract.

Section 79 adds to this as follows:

Operations carried on under and in accordance with an order made under this Part shall, for all purposes, be deemed to be carried on on each tract and the portion of unit or pooled production allocated to each tract, and only that portion, shall, for all purposes, be deemed to have been produced from that tract within the meaning of the terms and provisions of each lease or contract applicable to that tract.

Taken together these provisions have the following effects. ${ }^{239}$ First, operations, drilling or production, (and all operations incidental ${ }^{240}$ thereto) anywhere within the DSU will be deemed to be operations or production on each tract for the purposes of lease continuation. Second, royalty will be calculated and payable under the terms of any leases or contracts in accordance with the production allocated to that tract by the pooling order and not the production that might actually occur on that tract, or on the basis of any different allocation provided for in the lease or other contractual

See also the discussion in Bankes, supra note 1 at 534-35. The discussion at that point also refers to $\mathrm{s.} 9$ of the $O G C A$. In Ironwood Petroleum, supra note 85, Bearspaw argued that the appointment of an operator and the issue of penalty were the subject of an old contract affecting the property. The examiners rejected that contention (ibid. at 3) noting that "under section 9 of the Act, any pooling order issued by the Board would override the provisions of any contract or other arrangement conflicting with the order. This would apply to all aspects of the order, including the appointment of an operator under the pooling order and any penalty provisions which may be set out in the order." 
documents. The only uncertainty surrounding these two clauses might be as to the effect of a shut-in well ${ }^{241}$ on the spacing unit, but much would depend upon the terms of the individual leases.

\section{AMENDMENTS AND THE BOARD'S CONTINUING JURISDICTION}

\section{A. CONTINUING JURISDICTION}

The Act deals explicitly, and in some detail, with the circumstances under which the Board may amend a pooling order. Those provisions are reviewed in the next section. In addition, the terms of the Board's standard form order reserves to the Board continuing jurisdiction over the implementation of the terms of the order. In the typical order, ${ }^{242}$ there are no less than three instances in which the Board provides that, in the event of a dispute between the parties, "the dispute shall be referred to the Board and the Board's decision shall be final." These situations are:

- in the event of a dispute between the operator and an owner who elects to take in kind as to the point of delivery of the tract's share; ${ }^{243}$

- in the event of a dispute between the operator and an owner as to the operating expenses of the well or the tract's share of such expenses; ${ }^{244}$ and,

- in the event of a dispute between the operator and an owner as to the cost of drilling and completing the well or the tract's share of the costs. ${ }^{245}$

The extent to which the Board can claim exclusive jurisdiction over any of these matters is debatable. ${ }^{246}$ Equally debatable is the extent to which a party may request the Board to resolve a dispute as to a term of the order over which the Board has not expressly asserted continuing jurisdiction. For example, while the Board claims continuing jurisdiction over disputes as to place of delivery when a tract owner agrees to take in kind, what about a dispute as to "the current price in the field"? Must an owner refer such a dispute to a superior court or can it require the Board to assume jurisdiction over the matter? The cost implications of a superior court application may make this an important decision for an owner.

This eventuality is not specifically dealt with in either clause but perhaps it is subsumed under the term operations or is an activity incidental to an operation. The point might also be dealt with by the terms of the relevant leases.

242 See for example Order No. P 145, supra note 128.

243 Ibid., s. 6(3).

24s Ibid., s. 7(3).

2us Ibid., s. 8(4).

246 For a recent review of the relevant case law see Ulster, supra note 78 at 147 (paras. $47 \mathrm{ff}$ ). In that case Fraser J. discusses Calgary and Edmonton Corp. v. British American Oil Co. Ltd. (1963), 40 D.L.R. (2d) 972 (Alta. S.C. (A.D.)); Rabson v. Shell Oil Co. (1953), reproduced as Digest 69 in Canadian Oil and Gas, supra note 172, Canada (Minister of Energy Mines and Resources) v. Canada (Auditor General) (1989), 61 D.L.R. (4th) 604 (S.C.C.); and see also Mesa, supra note 81. 
Few cases exist in which the Board has exercised its continuing jurisdiction. In the Gulf Fenn-Big Valley application the Board issued two addenda to its original decision "clarifying" aspects of its main decision. The first addendum dealt with the allocation of drilling and completion costs for a multi-zone completion deep well and the time by which tract owners must pay their share of costs in order to avoid penalty. ${ }^{247}$ The second addendum dealt with cost allocation for multi-zone completions in the event that different pooled zones were brought into production successively. ${ }^{248}$ Other examples of continuing jurisdiction include orders extending the time for drilling the prescribed well, ${ }^{249}$ and one old decision stipulating that maintenance expenses, incurred while a well was shut in because of an emergency at the gas plant, were deemed to be operating expenses for the purposes of the order. ${ }^{250}$

\section{B. AMENDMENTS}

The Board's jurisdiction over amendments, variations to, and termination of, pooling orders is outlined in s. 74 of the Act. Amendments may be initiated by the Board itself or by tract owners. Where the application is initiated by a tract owner, the Board must consider an application if it is presented by the owners of at least 25 percent of the working interests in the DSU (calculated on an areal basis), ${ }^{251}$ and may do so if the application is presented by "any owner" if the Board "is satisfied that it is appropriate to do so." The Board's jurisdiction to consider an amendment, variation or termination of its own motion is triggered if the Board is of the opinion that pooling is no longer necessary to make up a spacing unit, if a well required by the order is not drilled within six months of the order, or if the well obtains production of a kind other than that for which the order was made.

In any case in which the Board initiates the matter it must hold a public hearing, but in other cases it may consider the application administratively. Subsection (3) appears to provide a list of the circumstances in which a change (including termination) may be made to the order: an amendment to supply a deficiency, or to meet changing circumstances, or to change or revoke any provision that is unfair or inequitable. All of this is subject to the further condition contained in subsection (3) that there shall be no change to the allocation of production or the basis for determining an owner's share of the cost of drilling, operation or abandonment of the well unless all tract owners within the DSU agree. ${ }^{252}$

Addendum 1 to D 90-9, supra note 6 and especially note 149 .

Addendum 2 to D 90-9, supra note 6 and especially note 151. In Ashlu, supra note 5 at 5 the Board indicated that it had the continuing jurisdiction to resolve disputes over the allocation of drilling costs to different formations if the parties could not agree.

See stipulation pursuant to Order No. P 47, supra note 53.

Order No. P 14A (5 January 1962), Devon-Palmer Oils Ltd., Compulsory Pooling, Okotoks Field. OGCA, supra note 4 , s. 74(1)(b).

Ibid., s. 74(3). See Westhill Resources Ltd., Section 22, Township 54, Range 25, West of the 4th Meridian, Campbell-Namao Campbell Blairmore A Pool, Campbell-Namao Field, Decision D 8541. This was an application for termination of Order No. P 38 (17 December 1973), R.J. Churchill Ltd., Compulsory Pooling, Campbell-Namao Field; and its replacement by a special spacing order. The Board noted that the original pooling order had provided for reserves-based pooling. The Board agreed to the termination of the order once it was satisfied that there were no objections. 
Finally, as noted above, ${ }^{253}$ the Board may, of its own motion, without holding a hearing, and without the approval of the Lieutenant Governor in Council, terminate an order if the order required that well was to be drilled within a time specified in the order and the well has not been drilled. ${ }^{254}$

The Board has considered several applications for amendment over the years but, to this point, those applications seem to have been relatively non-contentious ${ }^{255}$ and have been concerned primarily with matters of form, such as a change of the parties to the order, or a change in the name of the operator, ${ }^{256}$ rather than an issue of substance. The Board has terminated orders if the formation is shown to be unproductive and the leases expire. ${ }^{257}$ In appropriate cases the Board has issued a new order rather than amend an existing order, such as in a case where the applicant wishes to include an additional zone within the ambit of the order and the tract owners differ as between the two zones. ${ }^{258}$

In some circumstances, changing the name of the operator may be more than simply reflecting a corporate amalgamation. One of the implications of the appointment of an operator under a compulsory pooling order is that the parties do not have the benefit of the CAPL provisions on replacement of an operator in certain conditions such as insolvency, or by way of the challenge of an operator. ${ }^{259}$ Thus, in the case of insolvency, the only way to proceed is by way of application to the Board as happened in the Oilbank Resources Ltd. decision of the examiners. ${ }^{260}$

In effect, the Board agreed to replace the pooling order with one LSD spacing for the existing well; the case involved a concurrent production scenario.

Supra note 24.

OGCA, supra note 2 , s. 74(4).

One exception may be Voyager Petroleums (II) Ltd., Amend Board Orders No. P 41 and P 56, Norris and Warwick Fields, Examiners' Report E 85-10. This was an application to change the name of the operator from that of Voyager Petroleums Ltd. to Voyager Petroleums (II) Ltd. following a court approved plan of arrangement. Mr. Lazarenko, Q.C. intervened raising a series of objections not directly related to the change of name (e.g. defaults in payment of production). The examiners ruled that these issues were not relevant to the particular amendments sought and granted the application.

Ibid.

See Board Initiated Rescind Orders No. P 2, P 3, P 17, P 23, P 36, P 42, P 46 and Amend Order No. $P$ 50, Examiners' Report E 83-25. Actually, the application seems to have been initiated by the Department of Energy which seems to have been concerned to ensure that subsequent Crown lessees were not bound by continuing orders. See also Compulsory Pooling Order, Order No. $P$ 16, St. Albert Big Lake Field, Decision D 82-25, another example of a Crown initiated rescission. Does this mean that the Crown, as lessor, is an "owner" for the purposes of $s .74(1)$ and perhaps for the purposes of $\mathbf{s}$. 72? See discussion above, text accompanying notes $30 \mathrm{ff}$.

Voyager Energy Inc., Compulsory Pooling, Holmberg Field, Examiners' Report E 88-3.

See CAPL 1990, supra note 127, art. 2.

Oilbank Resources Ltd., Amendment of Compulsory Pooling Order No. P 70, Wainwright Field, Examiners' Report E 87-11. Actually, this may be far more efficacious than the challenge and replacement provisions of the CAPL because the case law suggests that it is actually very difficult to get rid of an operator who decides to fight. See DSWK Holdings v. Mutual Oil and Gas Lid. (12 June 1996), (Alta. C.A.) [unreported]; Rimoil Corp. v. Hexagon Oil and Gas (5 May 1989), (Alta. Q.B.) [unreported]; Tri-Star Resources v. JC International Petroleum (1986), 48 Alta. L.R. (2d) 355 (Q.B.); Norcen Energy Resources v. Oakwood Petroleums (1983), 63 Alta. L.R. (2d) 261 
An Examiners' Report upon an application of the City of Medicine Hat ${ }^{261}$ provides a slightly more unusual amendment case. The examiner had to deal with three issues: (1) changes in the parties subsequent to the original order; (2) provisions for missing tract owners; and (3) provision for the drilling of a second well to a different formation. At the time of the original application, the working interest owners within the unit had agreed upon a voluntary pooling and operating agreement, except for the tract owners for forty-one hectares who could not be traced. The original order had not provided for the involvement of the Public Trustee as provided for by s. 77 of the OGCA. ${ }^{262}$

In granting the application, the examiner amended the order to provide for inclusion of the Public Trustee and changed the designation of the producing zone to include all zones down to the zone to which the second well was to be drilled "since the mineral ownership is consistent throughout the section." ${ }^{263}$ The examiner also agreed to the drilling of the well within twenty-four months and agreed to the proposal that the well should be drilled in accordance with the terms of the voluntary pooling and operating agreement. $^{264}$

In a 1985 application from Cardo Canada, the Board recommended amendment of an order so as to delete reference to all horizons below the Bow Island Formation on the bases that these deeper horizons were non-productive and that the lease for one tract within the spacing unit only granted rights down to and including Bow Island. ${ }^{265}$

An innovative proposal from an intervenor to provide for a review of the terms of a pooling order after one year was rejected by a panel of examiners in an application from Elmtree Oils Ltd. ${ }^{266}$ Elmtree owned the gas rights in the SE quarter and had drilled a successful basal quartz sandstone well. Elmtree contended that the well had discovered a pool covering approximately a quarter section, and further indicated that the pool was not in communication with adjacent pools. Canada Northwest held the gas rights to the west half and suggested that it would agree to a 100 percent allocation of costs and revenues to Elmtree for one year during which time adjacent wells would be monitored to see if there was communication. ${ }^{267}$ After the elapse of one year presumably the Board would revisit the allocation. The examiners did not comment on the proposal and instead divided production 50:50 between the west half and the SE quarter. ${ }^{268}$

(Q.B.).

Medicine Hat, supra note 100.

Ibid. at 22 .

lbid. at 23 .

lbid. at 23-24.

Cardo Canada Ltd., Amend Order No. P 64, Eyremore Field, Examiners' Report E 85-8.

Elmtree, supra note 90.

Jbid. at 21 .

Ibid. at 21-22. 


\section{POOLING ORDERS AND UNITIZATION}

Several problems have already been noted above associated with pooling within a spacing unit when some, but not all, tracts are already included within a unitization agreement. ${ }^{269}$ The Act makes no specific provision for this eventuality, but it does contain a provision, s. 76, which is designed to deal with the situation in which a pooling order has already been made and the spacing unit subject to the order is subsequently included in a unitization agreement. The section both authorizes this to occur and specifies that the pooled lands will enter the unit as "a single unit tract." The section also stipulates that the order shall be deemed to be amended so as to provide that production and expenses allocated to the pooled lands under the terms of the unitization agreement shall continue to be shared by the tract owners in the pooled unit in the same manner as contemplated by the pooling order. Finally, the section notes that the Board may make any further changes that it deems "necessary or desirable for the purposes of making the order conform with the provisions for unit operation in the filed unit agreement."270

\section{POOLING VERSUS SPECIAL SPACING ORDERS}

As discussed above, voluntary pooling is the normal solution to the situation in which a mineral owner does not own or control the mineral rights throughout the spacing unit. If a voluntary agreement cannot be reached, the owner would, in the ordinary course, apply for a compulsory pooling order from the EUB. In some circumstances, however, another regulatory option may be available: an application for a special spacing unit order from the Board.

\section{A. THE REGULATIONS}

The Board's jurisdiction to grant an application for a special spacing unit is found in what are now ss. 4.040 and 4.050 of the Oil and Gas Conservation Regulations. ${ }^{271}$ There are many reasons for a mineral owner to seek a special spacing unit order. ${ }^{272}$ This section deals only with applications in which reduced spacing is sought as an alternative to pooling.

Of the two sections of the regulations, s. 4.040 is the more important because it is the general section. Section 4.050 is concerned with the specific case of a fractional section which, although not defined by either the Act or the Regulations, means a section that is reduced in size because of the application of the survey system. Thus,

\footnotetext{
269 See supra note 45.

270 For an example of an order amended in light of this section see Order No. P 20A (24 July 1962), Bailey Selburn Oil and Gas Ltd., Compulsory Pooling, Crossfield Formation.

27 Supra note 9. In addition to these two sections, s. 15.160 prescribes the information that an applicant must file in support of its application. An applicant must, inter alia, identify the lessors and lessees in the area and must address equity issues. The inquiry does not extend to royalty interests.

272 E.g. enlarged spacing to avoid off-target penalties: see Home Oil Company et al., Special TwoSection Gas Drilling Spacing Unit, Hamburg Area, Decision D 91-8.
} 
the sections abutting the meridians of longitude may be fractional sections, comprised of less than the full 640 acres. ${ }^{273}$

The regulations describe a "special DSU" as a DSU that differs from normal spacing units "in size, shape or target area." 274 This portion of the article deals solely with DSUs that differ in size. The jurisdictional portion of $\mathbf{s .} 4.040$ provides as follows:

(3) The Board shall not grant an application for an order pursuant to subsection (1) that would reduce the size of drilling spacing units to less than the size of normal drilling spacing units unless the applicant shows that

(a) improved recovery will be obtained,

(b) additional wells are necessary to provide capacity to drain the pool at a reasonable rate that will not adversely affect the recovery from the pool,

(c) the drilling spacing units would be in a pool in a substantial part of which there are drilling spacing units of such reduced size, or

(d) in a gas field, increased deliverability is desirable.

Note that the section is written in mandatory and exhaustive terms. On some occasions the Board has relied upon the mandatory and apparently exhaustive nature of the language to dismiss an application. In other cases, the Board has granted applications, even where an applicant's claim of improved recovery is highly speculative or insignificant in amount.

In effect, the Board has, by its practice in these latter cases, created additional categories of situations in which it will contemplate such applications. It is suggested here that one such additional category is where the applicant establishes that it would be inefficient or otherwise inappropriate to require pooling. ${ }^{275}$ In these cases, the Board emphasizes that it will interpret the regulations in light of the objects of the $O G C A{ }^{276}$ Thus, the Board will grant an application, if it tends to promote the equity and efficiency purposes of the Act, even though there is only nominal or speculative compliance with the improved recovery requirement of the regulations.

In this context, the two most widely quoted purposes of the Act are: ${ }^{277}$

For relevant decisions see Union Pacific Resources Inc., Special Gas Well Spacing, Ferrybank Area, Decision D 87-18; and Rustum Petroleums Ltd., Special Gas Well Spacing, Cygnet Area, Decision D 89-1.

Supra note 9, s. 4.040(1).

In other cases, the Board has permitted reduced spacing so as to avoid inequity: see Home Oil Company Ltd., Reduced Drilling Spacing Units, Wood River Field, Decision D 90-19. In that case a pool primarily located under the east half of section 21 was being drained from on-target wells located in the comers of adjacent spacing units, resulting in drainage. These offsetting spacing units were underlain by a tiny portion of the reserves. The Board found technical compliance with the regulations insofar as reduced spacing would allow some improvement in recovery, but the real ground on which the application was granted was that of equity.

Supra note 2, s. 4.

Ibid. 
(c) to provide for the economic, orderly and efficient development in the public interest of the oil and gas resources of Alberta;

(d) to afford each owner the opportunity of obtaining his share of the production of oil or gas from any pool.

To illustrate these points this section discusses one clear decision in which the Board denied an application for special spacing and two others in which the application was granted notwithstanding the applicant's difficulty in bringing itself within ss. 4.040 and 4.050 of the Oil and Gas Conservation Regulations.

In Spitzee Resources, ${ }^{278}$ the applicant applied for half section spacing for Gething gas production in sections 9,10 and 16 . Spitzee drilled an on-target well in the NW quarter of section 10 with the primary objective of Triassic oil production. However, the well was completed as a gas well in the Gething. Subsequently, Spitzee participated in a second well, later declared to be on target, in the SE quarter of section 16. This second well was completed for oil production in the Triassic. Spitzee owned the mineral rights in the east halves of 9 and 16 but the rights in the west half were owned by Chevron and Gulf. The decision does not indicate what the ownership rights were in section 10 .

Spitzee commenced pooling discussions with Gulf and Chevron but, according to Spitzee, "subsequent engineering studies showed that a reduction in spacing was more appropriate."279 Pooling negotiations were discontinued and Spitzee commenced its reduced spacing application. It supported its application by contending that pool size in the Gething ranged from less than half a section to larger than three sections, and that the pools within the area of application were discontinuous. It also argued that low permeability indicated that reduced spacing was required in order to maximize gas recovery. All of these views were contested by Gulf/Chevron.

The examiners rejected the application on the grounds that Spitzee had failed to meet any of the criteria established by the regulations. At best the application was premature. The examiners made it clear that the burden on the applicant was a high one and appropriately so: ${ }^{280}$

The examiners are cognizant of the precedent-setting effect and irreversible nature of any approval of reduced spacing. Therefore, in considering Spitzee's application, the examiners believe that they must be very confident that reduced DSUs are appropriate.

The examiners then continued with their analysis of the application: ${ }^{281}$ 
Considering the lack of data confirming reservoir quality and pool size .... in the application area, and considering no reduced DSUs exist for Gething gas ... to date, the examiners conclude that Spitzee did not provide evidence which would clearly satisfy one of the four possible criteria for approval of reduced DSUs.

The Spitzee Resources decision is a fairly straightforward case. In other cases, if well results have delineated the pool boundaries with much greater certainty, the Board is more likely to be swayed by the application. A case in point is the 1987 GNE Resources decision of the Board. ${ }^{282}$

GNE, the lessee of the SE quarter, drilled a Viking gas well (8-19). Gulf claimed to be the lessee of the north half of the section; the south west quarter was not leased. GNE applied for reduced quarter section spacing, arguing that its 8-19 well encountered a small pool extending over no more than four hectares. It contended that the pool might extend into the adjacent section but was "not likely to extend into the southwest quarter or north half of section 19."283 GNE offered two additional arguments in favour of the application. First, it noted that if the application were granted, other working interest owners in the section would be able to drill their own wells for other separate Viking pools within the section. ${ }^{284}$ Second, it noted that while it had other alternatives, namely voluntary pooling or compulsory pooling, the procedure for compulsory pooling was cumbersome and would involve delays.

Gulf objected to the application. It contended that the pool in question might extend into the northern half of the section and, in any event, GNE had not brought its application within s. 4.030(3) of the regulations and therefore to grant the application "would be an affront to the Regulations." Presumably, Gulf also meant that it would be illegal! The Board characterized Gulf's case as a claim that if there were several small gas accumulations within a section, then each should be pooled amongst the owners of the section. The Board disagreed and offered some general guidance:

The Board's view is that as a rule, where a natural gas reservoir extends over several sections of land or even a significant portion of a section, adherence to the one section DSU pooling approach best satisfies both sections 4(c) and (d) [of the $A c t$ ]. However, where the areal extent is much less than one quarter section, reduction of the gas DSUs to one quarter section may better satisfy both sections 4 (c) and (d). ${ }^{285}$

GNE Resources Ltd., Reduced Well Spacing, Provo Field, Decision D 87-5.

Ibid. at 1 .

The suggestion here seems to be that no further Viking wells could be drilled in the section in the absence of a special DSU order. However, while the failure to make a special order might have had an inhibiting effect, s. 12(3) of the OGCA only prohibits applications for licences "for a well for the purposes of obtaining production from the same pool as that from which another well is obtaining or capable of obtaining production in the same drilling spacing unit." The section goes on to reserve further discretion to the Board.

Ibid. at 2. In Ironwood Petroleum, supra note 85, the examiners left it open (ibid. at 9) to Bearspaw to bring a special spacing unit application in the event that subsequent tests established that the 2-18 well that was made the subject of the pooling order was either in limited communication with, or isolated from, the Basal Quartz pool encountered by Bearspaw's 14-18 well. The examiners also noted that if this happened it would be necessary to seek to amend the 
The Board dismissed the compulsory pooling option, castigating it as unnecessarily complicated and impractical. Faced with such an obstacle, the Board speculated that GNE might well forego any attempt to recover the small reserves associated with the 8-19 well. That conclusion also allowed the Board to satisfy itself that the application had indeed met one of the criteria set out in the regulations, namely, recovery of reserves that would otherwise be forfeit.

Another case in which the Board granted the application is the recent examiners' report concerning an Esso Resources application for the Leduc-Woodbend Field. ${ }^{286}$ As part of the blow-down of the Leduc Woodbend D-3 A Pool, Esso proposed to drill a number of additional gas wells to locate edge pinnacles and structural highs. Most of the wells were to be located within existing unit operations, and Esso's application for a relaxation of Part IV of the Regulations was non-contentious. However, Esso also sought approval for one LSD spacing for sections, only portions of which were contained within existing units. One section in particular proved contentious. The entirety of the section 28 rights were owned by the Crown. All of the section was within the D-3 Unit with the exception of LSD 5 leased to Esso, and LSDs 13 and 14 leased to Moraine. Esso indicated that it intended to drill a well on LSD 1 but also wanted future flexibility in developing its blow-down program. Confronted by Moraine with the options of compulsory pooling option, or an extension of the Unit, Esso argued that pooling with an allocation of a zero participation factor, or unitization with a zero tract participation factor was an administrative waste of time. In support of its position, Moraine offered an interpretation of the data which suggested that gas reserves would underlie its LSDs 13 and 14.

The examiners accepted Esso's arguments and granted the single LSD application. Here are their comments on their evaluation of the differences in the interpretation of the seismic data as between Esso and Moraine.

In the examiners' view, the seismic data submitted is inconclusive in determining the presence of Leduc reefs in Lsds 13 and 14. In the examiners' opinion, although Leduc reef may be present in Lsds 13 and 14 , it is unlikely that full reef build-up occurs with gas reserves in the upper Leduc. The examiners conclude that, as there appears to be a low probability that there are reserves underlying Lsds 13 and 14, pooling of the Leduc interests in the unit and non-unit portions of Section 28 would be inequitable for the unit. ${ }^{287}$

pooling order so as to ensure that the pooling order did not conflict with the special spacing unit order.

286 Esso Resources Canada Ltd., Special Gas Spacing, Leduc Woodbend Field, Examiners' Report E 92-3.

287 Ibid. at 6. One other decision of the examiners, Phoenix Resources, supra note 147, goes even further. In that decision the Board agreed to a special DSU of three quarter sections covering the NW quarter of one section combined with the south half of the diagonally offsetting section to the north. The applicant had drilled an off-target well in the SW quarter of the offsetting section. The Board granted the application on the basis of geological evidence that showed that "in all probability" the pool only extended to the three quarter sections in question (ibid. at 9). Somewhat contradictory was the Board's treatment of the same applicant's concurrent request for a compulsory pooling order. The Board granted the order, but ruled that the allocation of costs and production should be on an areal basis "due to the uncertainty of the size of the gas pool and the 


\section{CONCLUSIONS}

The jurisdiction of the Board to grant compulsory pooling orders is an essential part of the provincial well spacing regulations and the overall conservation rules for oil and gas production. Introduced in 1957, the relevant provisions of the Act have changed remarkably little since. During that 40 year period, the Board has issued 150 orders an average of less than 4 per year. Until 1988, the Board was required "to hear" all applications for compulsory pooling and so, until that year, no matter how straightforward the application (e.g. a name change or a routine missing tract owner matter), Board orders were supported by the reasoned decisions of the Board itself or its examiners. Since then matters are referred to the Board or its examiners in about one in three cases; for the remainder, there is simply a final pooling order.

This conclusion will address four matters: first, the consistency of Board decisionmaking; second, the adequacy of the Board's reasons; third, the continued involvement of the Lieutenant Governor in Council, and finally, the extent to which tract owners under a compulsory pooling order are in a more favourable position than they would likely be in under the terms of a voluntary pooling and operating agreement.

For the most part, the Board's practice as revealed in its reasons has been remarkably consistent on most of the topics canvassed above, any differences largely being explainable in terms of differing fact patterns. Although inconsistent treatment of a number of specific topics has been noted, ${ }^{288}$ the area of Board practice that seems the least predictable is its treatment of equalization, especially in the contexts of concurrent production and multiple completions. Thus, in the case of a well drilled by the

highly interpretive nature of the geology in the area of application" (ibid. at 10). Thus there was sufficient certainty for the Board to order special spacing but insufficient certainty to allocate production on anything other than an areal basis, yet of course the creation of the special DSU had in itself effected a much more serious reallocation of reserves from the standard DSU to the special DSU. On occasion operators may induce the Board to be even more creative. A case in point is Roxy Petroleum Ltd., Reduced Gas Well Spacing, Viking-Kinsella Field, Examiners' Report E 84-2. Roxy owned the mineral rights in the Viking formation in section 27 and drilled the 6-27 well which was placed on production in 1956. In 1980 Signalta drilled the 14-27 well in an unsuccessful attempt to test for hydrocarbons in deeper formations. Roxy subsequently acquired the rights to the 14-27 well which was also capable of producing from the Viking. Roxy sold gas from a number of wells in the area to the town of Wainwright and found that during peak demand it needed to supplement supply by purchasing from NUL in order to meet its contractual obligations. To alleviate this problem, Roxy proposed that it be allowed to produce both the 14-27 and 6-27 wells. Roxy admitted that half section spacing would not have a significant effect on ultimate recovery and was not needed in order to adequately recover Viking reserves in the area (ibid. at 12). Luscar, which owned the rights to the offsetting section 34, objected to the proposal. Luscar and Roxy had attempted without success to negotiate a two section pooling agreement. Nevertheless, despite Luscar's objections and Roxy's admissions, the Board approved half section spacing on terms acceptable to Roxy - namely that annual production from the two wells taken together not exceed the then current annual volume for the one well. In the view of the examiners, this arrangement would satisfy Roxy's requirements and, at the same time, protect Luscar from further and inequitable drainage (ibid. at 43).

E.g. appointment of more than one operator under the terms of an order; and designation of pooled formations. 
applicant to evaluate a deeper formation (oil or gas) there is a uniformity of practice in excluding all costs associated with the drilling (and completion) of that well in any formation below the zone for which a pooling order is sought, but a wide range of opinion in the treatment of the original cost of drilling the well to the pooled formation. In several cases applicants have not sought to equalize costs at all and the Board has approved of that arrangement. ${ }^{289}$ In other cases, the Board has required the applicant to discount the cost of the well by a further 50 percent, ${ }^{290}$ while in yet other cases the examiners have not required any further discounting. ${ }^{291}$ On the other hand, Board practice is consistent in the treatment of equalization costs for a well that will be completed in several pooled zones. ${ }^{292}$

If this assessment of the Board's decisions is correct on this particular point of discounting equalization costs for a well that is drilled at time $\mathrm{X}$ with objective $\mathrm{Y}$ in mind, and then subsequently recompleted at time $P$ with objective $Q$ in mind, what are the consequences? First, there are some very obvious practical consequences. If Board practice is inconsistent it will not assist the parties in reaching agreements without resorting to Board orders. Either party, or even both parties, may feel that (it) they will be able to get a better deal from the Board than they are (it is) able to obtain from a voluntary agreement. That will not only increase the work of the Board but it will also thwart what is one of the fundamental objectives of this part of the $\mathrm{Act}^{293}$ which is to encourage voluntary negotiations. Second, there may also be legal consequences associated with this (or any other lack of consistency). At an abstract level, the lack of consistency raises a legitimate concern as to the justness of Board decision-making if the Board is not treating similar cases in a similar way. At a more immediate level, it may make Board decisions more vulnerable to judicial review.

The Supreme Court of Canada considered the implications of inconsistent decisions on the availability of judicial review (in the context of a specialized and appellate labour tribunal) in the Domtar case. ${ }^{294}$ The tribunal in question was protected by a full set of privative clauses which declared decisions of the tribunal to be final and precluded judicial review except on jurisdictional grounds. ${ }^{295}$ The issue before the court was whether or not a tribunal decision on a matter related to the interpretation of a labour statute, that was not patently unreasonable, might be reviewed on the grounds that tribunal decisions on this same question (but in different contexts ${ }^{296}$ ) were inconsistent.

L'Heureux-Dubé J. gave the unanimous decision of the court. She noted that the court was faced with a difficult balancing decision. On the one hand there was the principle of autonomy of expert tribunals acting within their field of expertise,

Suncor, supra note 57; and Penn West, supra note 114.

Gulf Fenn-Big Valley, supra note 6; and Pembina Resources, supra note 85.

Imperial, supra note 154; and Gulf Leduc Gas, supra note 50.

See Gulf Fenn-Big Valley, supra note 6 and discussion above, text accompanying notes 144-51. OGCA, supra note 2, s. 71(1).

Supra note 7.

Ibid. at 391.

One was a civil case, the other a regulatory offence. 
especially where protected by a privative clause. From that perspective, inconsistent decision-making was simply a necessary consequence of a deferential standard of review. A test of patent unreasonableness admitted of the reality that there were several possible interpretations of the same statutory provision. Hence, where decisions were equally well reasoned, it was not appropriate for the court to pick and choose. ${ }^{297}$ Instead, there is a suggestion that the matter is largely one for the tribunal itself to establish internal checks and balances to prevent inconsistency. ${ }^{298}$ On the other hand, there were powerful arguments militating in favour of an independent review on the grounds of inconsistency. These arguments included the principle of equality before the law, the principle that similar cases should be accorded similar treatment, and the idea that consistency inspires confidence in the decision-making of the Board. ${ }^{299}$

In the result, L'Heureux-Dubé J. favoured the principle of autonomy. What are the implications of that decision for the EUB in the present context? First, it is important to note that while the EUB is protected by a range of privative clauses, their collective ambit is narrower than that considered by the court in the Domtar case. ${ }^{300}$ In particular, the $E R C A$ and the $E U B A c t^{301}$ expressly contemplate an appeal with leave, on questions of law as well as on questions of jurisdiction. This is important because it is fairly clear that, at bottom, the proper treatment of a subject like equalization is nothing more than a question as to the interpretation of the term "actual cost of drilling the well." That is clearly a question of law and not a question of jurisdiction. It is also a question on which the Board is expected to have special expertise. In an analogous statutory context, the Alberta Court of Appeal has stated that the standard of review applicable to a tribunal protected by identical privative and appeal clauses is that of correctness in relation to questions of law. ${ }^{302}$ While this opinion must now be read in light of the Supreme Court of Canada's decision in Bell (where the Court stated that some deference is appropriate even where a tribunal is subject to the appellate review jurisdiction of a superior court on the basis of specialization of duties ${ }^{303}$ ), it is clear that a reviewing court will not be as constrained in relation to the EUB as it would be in relation to a tribunal protected by a full privative clause.

Ibid. at 414.

See the reference ibid. at 417 to Consolidated Bathhurst Packaging Lid. v. International Woodworkers of America, Local 2-69 (1990), 68 D.L.R. (4th) 609 (S.C.C.).

Ibid. at 406-409.

See supra notes $80-81$.

Supra note 2, ss. 20-21.

Transalta Utilities Corp. v. Alberta Public Utilities Board (1986), 43 Alta. L.R. (2d) 171 at 179-82 (C.A.).

Bell Canada v. Canadian Radio-television and Telecommunications Commission (1989), 60 D.L.R. (4th) 682 at 699 (S.C.C.); and see also D. Jones \& A. de Villars, Principles of Administrative Law, $2 d$ ed. (Toronto: Carswell, 1994) at 426-29. Note that in Bell the Court in fact ruled (ibid. at 700) that the CRTC was not entitled to deference on the question of its powers to order a customer rebate as part of finalizing an interim decision. This suggests that as a matter of practice a Court may be able to determine how much deference is to be accorded to a decision-maker by the way in which it frames the issue in relation to what it characterizes as the tribunal's area of expertise. The Transalla case, ibid., provides another illustration of the same point. 
It is submitted here that the fact that the ERCA contemplates review on the basis of error of law is a potential basis for distinguishing Domtar. In Domtar, L'Heureux-Dubé J. noted that one way to put the issue was to ask to whom had the legislature entrusted the interpretation of the statute and the resolution of inconsistencies? ${ }^{304}$ In Domtar, the clear response was the Commission d'appel which could only be reviewed on jurisdictional grounds. In the case of the EUB the answer cannot be so clear. In part at least, the legislature has entrusted final determinations of questions of law to the courts. Where the Board is consistent, it would be appropriate for the court to show considerable deference but not in cases in which different panels reach different results. The cases on standard of review talk about a spectrum. ${ }^{305}$ At one end of the spectrum is a decision-maker like the Commission d'appel in Domtar fully protected by a privative clause, interpreting its own statute and entitled to a high degree of deference. At the other end of the spectrum is a decision-maker acting without the benefit of a privative clause making a decision on a matter of general law and entitled to little deference. The EUB lies somewhere between these two extremes. A pattern of inconsistent decision-making, a jurisprudential conflict, may be sufficient to persuade a reviewing court to intervene.

Second, L'Heureux-Dubé J. placed some importance on the invidiousness of the court being asked to choose between equally well-reasoned decisions. That of course begs the question: are different decisions of the Board or its examiners equally well reasoned, or additionally, might the absence of reasons itself provide grounds for judicial review?

Some Board decisions are models of clarity with conclusions fully supported by a chain of reasoning justifying both premises and conclusions. ${ }^{306}$ But in other cases, the Board or its examiners have simply not taken the trouble to justify a conclusion. ${ }^{307}$ Too often, the Board's lame response to a novel argument is that "it is inappropriate in these circumstances" ${ }^{308}$ with no justification offered as to what it is about the "circumstances" that is relevant to the conclusion, or what particular section of the Act justifies the conclusion that the relief sought is inappropriate. The consequences of this practice are again legal and practical. At a practical level, the failure to give reasons is a failure to offer guidance to other parties who may use that guidance to reach

Ibid. at 419.

Pezim v. British Columbia (Superintendent of Brokers) (1994), 114 D.L.R. (4th) 385 at 404-405. For example, the Gulf Fenn-Big Valley decision, supra note 6, or the examiners first attempt at dealing with the problems posed by pooling applications in a concurrent production scenario in the Suncor application, supra note 57.

This article does not intend to single the Board out for criticism on this point. Much the same criticisms could be levelled at the Court of Appeal of Alberta and its overuse of memoranda of decisions rather than more thoroughly supported reasons for decision (see for example the Court of Appeal's decisions referred to in notes 39, 95 and 260, supra).

E.g. Imperial, supra note 154 at 5: other deductions from actual drilling costs not "appropriate or relevant" (no explanation of why Gulf Fenn-Big Valley, supra note 6, should not be followed or why no allowance for incentive credits and royalty holidays), "not appropriate" to make equalization or penalty costs net of production revenues owed to Mutiny; Gulf Leduc Gas, supra note 50 at 5: "not necessary" to provide for a marketing fee; Mission Resources, supra note 33 at 5: it was not "appropriate to specify any other conditions respecting gas price." 
voluntary agreements as to their differences. Legally, the failure to provide adequate reasons is a breach of the Administrative Procedures $A c t^{309}$ and renders the decision vulnerable to judicial review.

What constitutes an adequate set of reasons is clearly a matter of some interpretive difficulty. ${ }^{310}$ Various guidelines have been suggested. Reasons must be proper, adequate and intelligible. They must enable the person concerned to address whether they have grounds for appeal or review. ${ }^{311}$ They must be more than a recitation of the evidence and must be more than a bare set of conclusions. ${ }^{312}$ They must show a chain or line of reasoning and must show that the decision-maker has heeded its statutory mandate. ${ }^{313}$ It is true that a court may find that the tribunal's obligation has been discharged by an inference that can be drawn from its skeletal reasons, ${ }^{314}$ but on any account, some of the reasoning offered by various panels of examiners is too conclusory to satisfy the statutory mandate.

The continued involvement of the Lieutenant Governor in Council in the process of issuing and amending pooling orders is anomalous and anachronistic. In the late 1950s when the idea of compulsory pooling was first introduced (at the same time that the possibility of compulsory unitization was first introduced into the $A c t$ ) it seems reasonable to conclude that the involvement of the Lieutenant Governor in Council was required as a necessary check in order to provide some level of political assurance for the industry that the Board would not be allowed to go off on a frolic of its own. ${ }^{315}$ But forty years and 150 pooling decisions later, the best protection for the industry is that the Board be required to provide written reasons for its decisions, that those reasons be consistent with previous Board practice, and that Board decisions continue to be subject to review on grounds of errors of law or jurisdictional grounds. ${ }^{316}$

In other cases in which the Act provides for Lieutenant Governor in Council approval ${ }^{317}$ the Board's practice suggests that this additional requirement is sometimes used very explicitly to encourage the parties to negotiate further. For example, in a recent common carrier application, the examiners considered it desirable to recommend

R.S.A. 1980, c. A-2, and Alta. Reg. $135 / 80$ as am. Both the ERCB and the Public Utilities Board (PUB) were listed under the regulations. The regulations have not been amended to make specific mention of the EUB but the EUB is, in effect, a continuation of the ERCB and the PUB and must therefore be subject to the Administrative Procedures Act in the same way as the predecessor Boards.

3to See Jones \& de Villars, supra note 303 at 306-307; and Re Petro-Canada, supra note 89.

31 Dome Petroleum Ltd. v. Public Utilities Board (1976), 2 A.R. 453 (C.A.), aff d(1976), 2 A.R. 452 (S.C.C.).

$312 \quad$ Northwestern Utilities Ltd. v. Edmonton (1978), 89 D.L.R. (3d) 361 (S.C.C.).

313 lbid.

$314 \quad$ See Re Petro Canada, supra note 89 at 495.

315 See Breen, supra note 11 at 500-502.

316 More precisely, appeal on a point of law or jurisdiction with leave of the court of appeal: see ERCA, supra note 5, ss. 44-45; and the EUB Act, supra note 2, ss. 20-21. (common processor); there is an appeal to the Lieutenant Governor in Council upon denial of a well licence (s. 14). 
to the Board that the Board's request for Order in Council approval should be delayed for two months so as to allow for additional negotiations which might then result in the withdrawal of the application. ${ }^{318}$ While this may serve a useful purpose in the context of the common orders given the far-reaching effect of such orders, it is questionable whether such an approach is lawful $\left.\right|^{319}$ and also questionable whether it serves a useful purpose in the context of pooling orders.

The final question this article shall attempt to address is the extent to which Board orders depart from customary practice in the industry and, to that extent, provide an incentive to tract owners to reject reasonable offers to secure the intervention of the Board. It is not claimed here that these differences have actually motivated parties in any particular case, but these differences may influence tract owners at the margins. The areas in which Board practice seems to be more generous to tract owners than general practice in the industry would seem to be as follows: a penalty that is limited to 200 percent of drilling and completion costs; ${ }^{320}$ assessment of penalty only upon drilling and completion costs; ${ }^{321}$ the operator bears an obligation to market a tract owner's share of production and is not entitled to charge a marketing fee; ${ }^{322}$ a tract owner may postpone a decision as to whether to go penalty until the well has actually been drilled and placed on production; ${ }^{323}$ and all liabilities of tract owners including the costs of abandonment are payable only out of production. ${ }^{324}$

Signalta Resources Ltd., Rateable Take/Common Carrier/Common Processor, Winborne Belly River B Pool, Examiners' Report E 95-4 at 11.

Would not the Board be subject to a mandamus order requiring it to seek an approval? If not the Board could effectively deny the application by continually postponing an application for $0 . C$. approval.

A larger penalty is not unusual in the industry (see Penn West, supra note 114 at 5); the CAPL 1990 form, supra note 127, distinguishes between development wells and exploratory wells. See also the decision of the Saskatchewan Court of Appeal in Gannon Brothers Energy Ltd. v. Robert Lemmons and Associates, [1996] S.J. $762(\mathrm{QL})$ in which the court confirmed that the penalty under CAPL 1990, para. 1007, was payable on the full amount of drilling or completions costs and not just that share of the costs attributable to the working interest share held by the joint operator. CAPL 1990, ibid., provides for a 200 percent penalty on equipping costs.

Contrast with cl. 602 of CAPL 1990, ibid., the operator has the authority but not the obligation to market another owner's share of production and in some scenarios the agreement accords the operator a marketing fee if it does market another owner's share of production.

Under CAPL 1990, ibid., a party is deemed not to participate in an independent operation unless it elects to participate within thirty days of receipt of the independent operation notice (cl. 1002(b)).

324 Under CAPL 1990, ibid, as soon as the penalty is discharged the non-participants have an election to make. In the event that they elect not to participate they forfeit their interest in the well; if they elect to participate they would become fully liable for abandonment which would be an operation for the joint account. This would be an ordinary debt. It would not be payable only out of production and the operator would have all the usual remedies available to an operator under CAPL. 